\title{
Chapter 8 Sensitivity and Uncertainty of Criticality
}

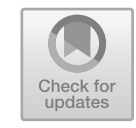

\author{
Masao Yamanaka
}

\begin{abstract}
Excess reactivity and control rod worth are generally considered important reactor physics parameters for experimentally examining the neutron characteristics of criticality in a core, and for maintaining safe operation of the reactor core in terms of neutron multiplication in the core. For excess reactivity and control rod worth at KUCA, as well as at the Fast Critical Assembly in the Japan Atomic Energy Agency, special attention is given to analyzing the uncertainty induced by nuclear data libraries based on experimental data of criticality in representative cores (EE1 and $\mathrm{E} 3$ cores). Also, the effect of decreasing uncertainty on the accuracy of criticality is discussed in this study. At KUCA, experimental results are accumulated by measurements of excess reactivity and control rod worth. To evaluate the accuracy of experiments for benchmarks, the uncertainty originated from modeling of the core configuration should be discussed in addition to uncertainty induced by nuclear data, since the uncertainty from modeling has a potential to cover the eigenvalue bias more than uncertainty by nuclear data. Here, to investigate the uncertainty of criticality depending on the neutron spectrum of cores, it is very useful to analyze the reactivity of a large number of measurements in typical hard (EE1) and soft (E3) spectrum cores at KUCA.
\end{abstract}

Keywords Sensitivity $\cdot$ Uncertainty $\cdot$ Criticality $\cdot$ Solid-moderated and solid-reflected core 


\subsection{Experimental Settings}

\subsubsection{Core Configuration}

The experiments of reactivity measurement [1,2] were carried out in the A cores (EE1 and E3 cores in Figs. 8.1a, b, respectively) that have polyethylene moderator and reflector rods, and different fuel assemblies: "F" and "f" (Figs. 8.2a, b, respectively). In EE1 core (Fig. 8.1a), fuel assembly "F" (1/8"P60EUEU) in Fig. 8.2a is composed of 60 unit cells, and upper and lower polyethylene blocks about $25^{\prime \prime}$ and $20^{\prime \prime}$ long, respectively, in an aluminum $(\mathrm{Al})$ sheath $\left(2.1^{\prime \prime} \times 2.1^{\prime \prime} \times 60^{\prime \prime}\right)$. For the fuel assembly, a unit cell in the fuel region is composed of two highly enriched uranium (HEU) fuel plates $1 / 8^{\prime \prime}\left(2 \times 1 / 16^{\prime \prime}\right)$ thick and a polyethylene moderator plate $1 / 8^{\prime \prime}$ thick. In E3 core (Fig. 8.1b), another fuel assembly " $\mathrm{f}$ " (3/8"P36EU) in Fig. 8.2b is composed of 36 unit cells with an HEU fuel plate $1 / 16^{\prime \prime}$ thick, polyethylene plates $3 / 8^{\prime \prime}$ thick, and upper and lower polyethylene blocks about $23^{\prime \prime}$ and $21^{\prime \prime}$ long, respectively, in the Al sheath as in fuel assembly "F". The neutron spectrum in EE1 core is compared with that in E3 core as shown in Fig. 8.3, demonstrating representatively hard (EE1 core) and soft (E3 core) neutron spectra in the KUCA A-core.

\subsubsection{Reactivity Measurements}

For measuring the excess reactivity, the critical state was adjusted by maintaining a certain position of $\mathrm{C} 3$ rod in $\mathrm{EE} 1$ core and $\mathrm{C} 1$ rod in $\mathrm{E} 3$ core, and by withdrawing fully the other control (C1 and $\mathrm{C} 2$ in EE1; C2 and C3 in E3) and safety (S4, S5, and S6) rods from the core, respectively. Furthermore, excess reactivities in EE1 and $\mathrm{E} 3$ cores were measured by the positive period method, when $\mathrm{C} 3$ and $\mathrm{C} 1$ rods, respectively, were, under the critical state, fully withdrawn from the core.

For measuring the control rod worth, in cases of $\mathrm{C} 1$ and $\mathrm{C} 2$ rods in EE1 core, criticality was maintained by $\mathrm{C} 3 \mathrm{rod}$, and the control rod worth of $\mathrm{C} 1$ or $\mathrm{C} 2$ rod was acquired by the rod drop method, after full insertion of $\mathrm{C} 1$ or $\mathrm{C} 2$ rod into the core. For $\mathrm{C} 3$ rod in $\mathrm{EE} 1$ core, criticality was adjusted by $\mathrm{C} 1$ rod, and the control rod worth of C3 rod was obtained by the rod drop method, after the full insertion of C3 rod into the core. Almost the same procedures were followed for the E3 core, with the use of the rod drop method, and the control rod worth of $\mathrm{C} 1, \mathrm{C} 2$, and $\mathrm{C} 3$ rods was obtained experimentally.

To estimate the experimental uncertainty of excess reactivity and control rod worth, the dimensions of the HEU plate comprising of core components are considered manufacturing tolerances among the significant factors taken into account, as shown in Table 8.1. In addition to the dimensions of the HEU plate, as previously demonstrated at the Fast Critical Assembly in the Japan Atomic Energy Agency [3], other important uncertainty factors include mechanical reproducibility of control rod position, measurement errors of doubling time by the positive period method, core 

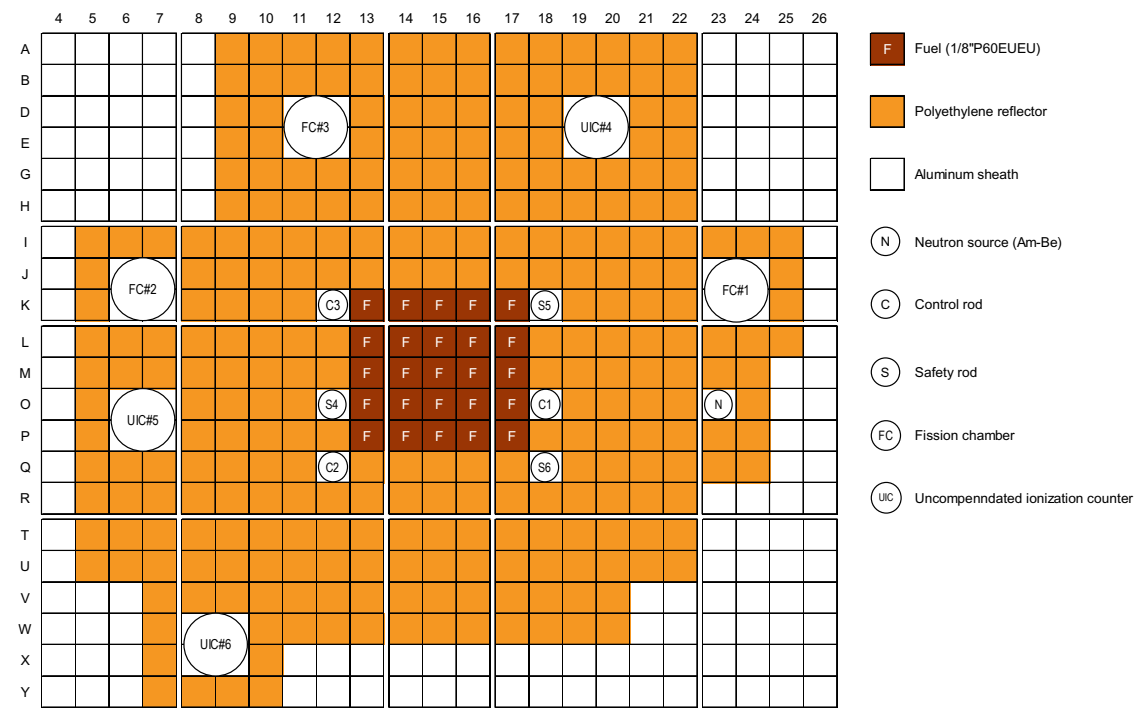

(a) EE1 core (1/8'P60EUEU)
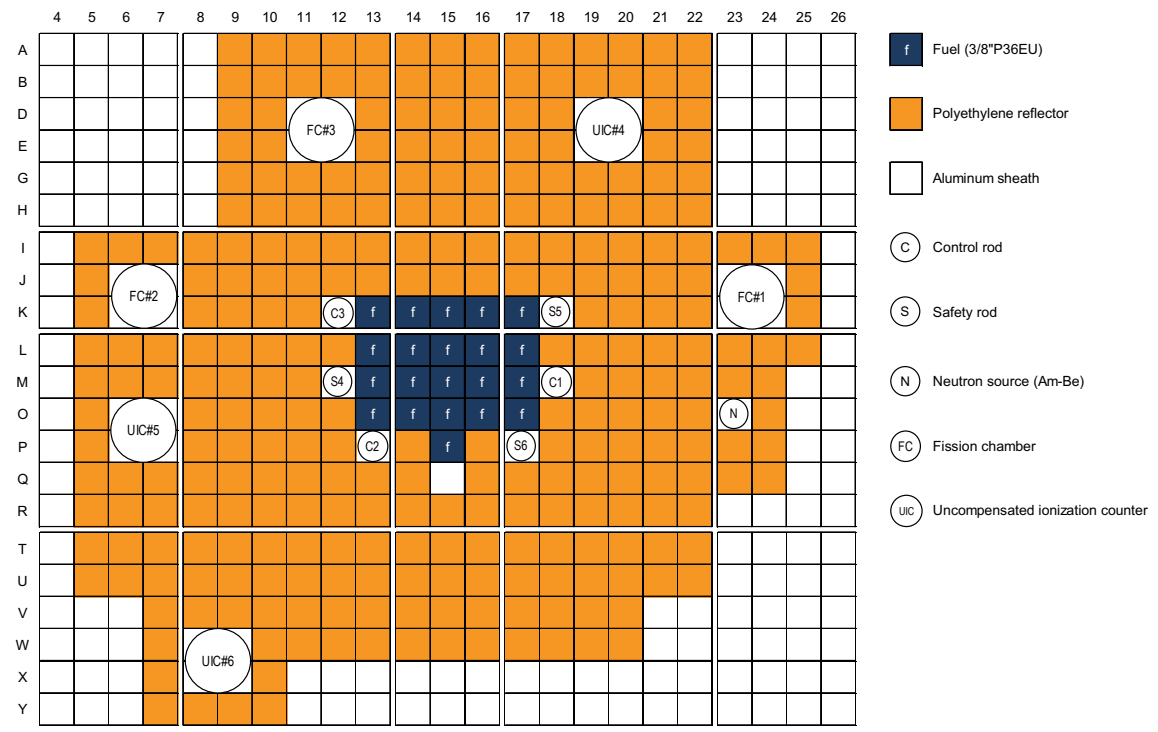

(b) E3 core (3/8'P36EU)

Fig. 8.1 Top view of KUCA A-core (Refs. [1, 2]) 


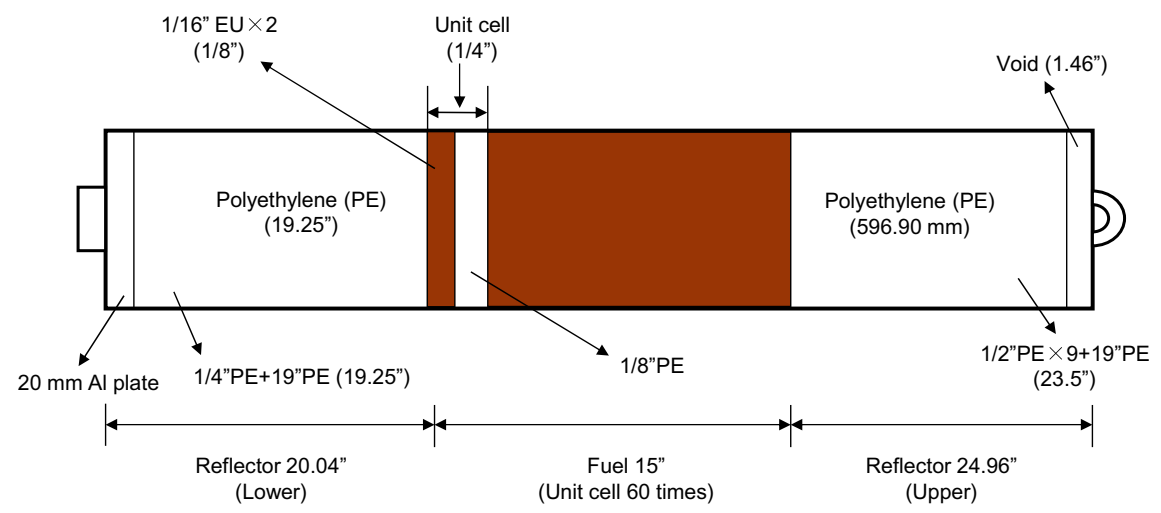

(a) Fuel "F" shown in Fig. 8.1(a)

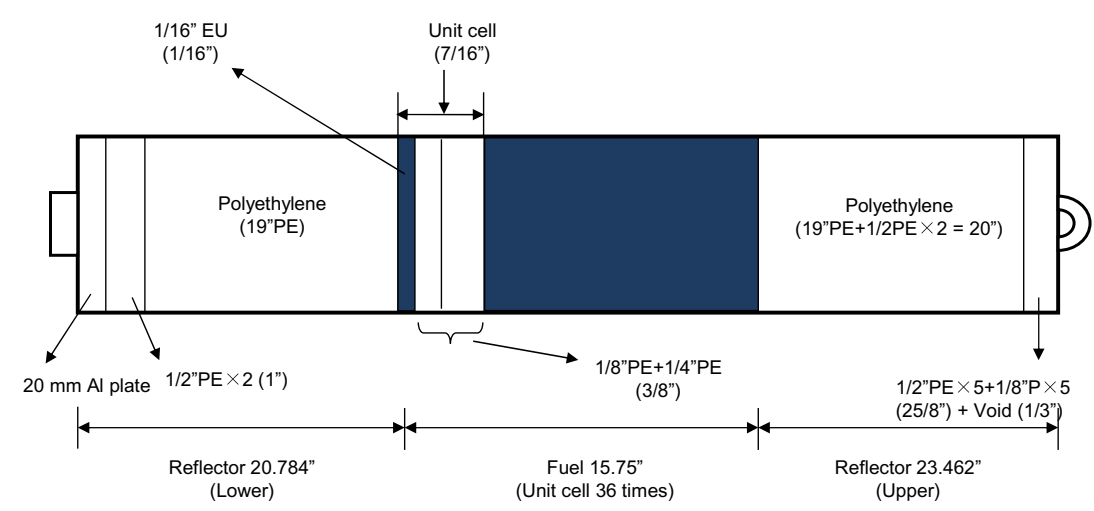

(b) Fuel "f" shown in Fig. 8.1(b)

Fig. 8.2 Description of fuel rods in A-core shown in Fig. 8.1 (Refs. [1, 2])

Fig. 8.3 Neutron spectra of EE1 and E3 cores shown in Figs. 8.1a, b, respectively (Refs. [1, 2])

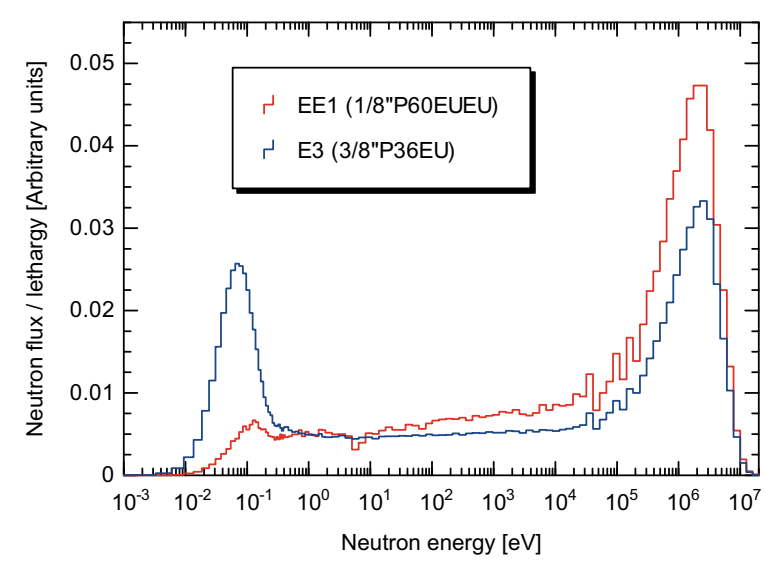


Table 8.1 Experimental uncertainties of HEU fuel plate (Refs. [1, 2])

\begin{tabular}{l|l}
\hline Cause of uncertainty & Error $(\%)$ \\
\hline Composition & 3.0 \\
\hline Length of both sides (one side: $0.2 \%)$ & 0.3 \\
\hline Thickness & 3.1 \\
\hline
\end{tabular}

Table 8.2 Measured results [pcm] of excess reactivity and control rod worth with standard deviation obtained from experimental data in EE1 and E3 cores (Refs. [1, 2])

\begin{tabular}{l|l|l}
\hline Reactivity & EE1 (error: \%) & E3 (error: \%) \\
\hline Excess & $210 \pm 6(3.1)$ & $264 \pm 2(0.8)$ \\
\hline C1 rod & $838 \pm 11(1.4)$ & $551 \pm 6(1.2)$ \\
\hline C2 rod & $144 \pm 3(2.4)$ & $429 \pm 4(1.0)$ \\
\hline C3 rod & $521 \pm 8(1.7)$ & $329 \pm 4(1.4)$ \\
\hline
\end{tabular}

EE1: $\beta_{\text {eff }}: 831 \mathrm{pcm}$ and $\Lambda: 3.027 \mathrm{E}-05$ s by MCNP6.1 with JENDL4.0

E3: $\beta_{\text {eff }}: 805 \mathrm{pcm}$ and $\Lambda: 4.771 \mathrm{E}-05 \mathrm{~s}$ by MCNP6.1 with JENDL4.0

temperature, delayed neutron parameters induced by numerical analyses, fuel composition uncertainty caused by heterogeneity distribution and deformation inside the $\mathrm{Al}$ sheath. Among these factors, the mechanical reproducibility of control rod position, in this study, was considered of great impact caused by tolerance and instability of control rod inside the $\mathrm{Al}$ sheath in a horizontal direction than the experimental uncertainty of excess reactivity and control rod worth, because the other uncertainties are relatively minor. Furthermore, heterogeneous arrangement of fuel plates in an axial direction was attributable to random selection of fuel plates for making fuel cells with a record number of fuel plates. Therefore, the experimental uncertainty of excess reactivity and control rod worth was finally determined to be about $3 \%$ at most by averaging the experimental data, and estimating its standard deviation, as observed in operations of the previous decade in the KUCA A-core, as shown in Table 8.2.

\subsection{Criticality}

\subsubsection{Numerical Simulations}

\subsubsection{Stochastic Calculations}

Excess reactivity was numerically deduced by the MCNP6.1 code [4] with the JENDL-4.0 [5] and the ENDF/B-VII.0 [6] libraries through the difference between the critical and super-critical states in the core; control rod worth was numerically obtained by the difference between critical and subcritical states. For the evaluation 
of excess reactivity and control rod worth, in the critical core, the effective delayed neutron fraction $\left(\beta_{\text {eff }}\right)$ was acquired by MCNP6.1 (2,000 active cycles of 50,000 histories; $5 \mathrm{pcm}$ statistical error) with JENDL-4.0. The values of $\beta_{\text {eff }}$ at critical state of EE1 and E3 cores were 831 and 805 pcm, respectively; those of the neutron generation time $(\Lambda)$ were $3.027 \mathrm{E}-05$ and $4.771 \mathrm{E}-05 \mathrm{~s}$, respectively. Atomic number densities of core components comprise fuel elements, moderator (reflector), control rod, and Al sheath, for analyzing experimental values of excess reactivity and control rod worth.

\subsubsection{Deterministic Calculations}

Numerical analyses by deterministic calculations were performed by combining the SRAC2006 [7] and the MARBLE [8] code systems: collision probability calculations (PIJ [7]) and eigenvalue calculations (CITATION [9]) of SRAC2006, sensitivity coefficient calculations (SAGEP [10]) and uncertainty calculations (UNCERTAINTY [8, 11]) of MARBLE, coupled with the JENDL-4.0 nuclear data library. Experimental analyses of uncertainty were conducted with the use of covariance data of cross sections contained in JENDL-4.0, including uncertainty of excess reactivity and control rod worth induced by the nuclear data, and the effects of decreasing uncertainty on the accuracy of excess reactivity and control rod worth. Here, in a series of deterministic calculations, the CITATION code was notably executed for obtaining sensitivity coefficients by the SAGEP code based on the diffusion calculations.

\subsubsection{Sensitivity and Uncertainty}

\subsubsection{Numerical Reactivity}

The experimental values of excess reactivity (positive value) $\Delta \rho_{\text {Excess }}^{\text {Exp }}$ and control rod worth (negative value) $\left(-\Delta \rho_{\mathrm{Rod}}^{\mathrm{Exp}}\right)$ were deduced by effective multiplication factors

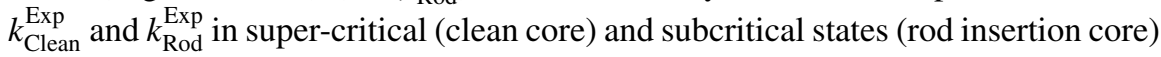
obtained by the positive period method and the rod drop method, respectively, as follows:

$$
\begin{gathered}
\Delta \rho_{\text {Excess }}^{\text {Exp }}=1-\frac{1}{k_{\text {Clean }}^{\text {Exp }},} \\
-\Delta \rho_{\text {Rod }}^{\text {Exp }}=1-\frac{1}{k_{\text {Rod }}^{\text {Exp }}} .
\end{gathered}
$$

In MCNP analyses, numerical value $\Delta \rho_{\text {Excess }}^{\mathrm{MCNP}}$ or $\left(-\Delta \rho_{\mathrm{Rod}}^{\mathrm{MCNP}}\right)$ was deduced by the difference between two effective multiplication factors $k_{\text {Clean }}^{\mathrm{MCNP}}$ or $k_{\mathrm{Rod}}^{\mathrm{MCNP}}$ and $k_{\text {Critical }}^{\mathrm{MCNP}}$ in the super-critical or subcritical and critical cores, respectively, as follows: 


$$
\begin{gathered}
\Delta \rho_{\text {Excess }}^{\mathrm{MCNP}}=\frac{1}{k_{\text {Critical }}^{\mathrm{MCNP}}}-\frac{1}{k_{\text {Clean }}^{\mathrm{MCNP}}}, \\
-\Delta \rho_{\mathrm{Rod}}^{\mathrm{MCNP}}=\frac{1}{k_{\text {Critical }}^{\mathrm{MCNP}}}-\frac{1}{k_{\mathrm{Rod}}^{\mathrm{MCNP}}} .
\end{gathered}
$$

In MCNP calculations, $k_{\text {Critical }}^{\mathrm{MCNP}}$ needs to be defined as the value of the effective multiplication factor in the critical core, since the numerical value is not always a unit.

On the basis of the experimental methodology shown in Eqs. (8.1) and (8.2), a numerical approach of excess reactivity $\Delta \rho_{\text {Excess }}^{\text {CITATION }}$ and control rod worth $\left(-\Delta \rho_{\text {Rod }}^{\text {CITATION }}\right)$ by deterministic calculations (CITATION) is generally expressed, respectively, as follows, as were experimental values:

$$
\begin{gathered}
\Delta \rho_{\text {Excess }}^{\text {CITATION }}=1-\frac{1}{k_{\text {Clean }}^{\text {CITATION }}}, \\
-\Delta \rho_{\text {Rod }}^{\text {CITATION }}=1-\frac{1}{k_{\text {Rod }}^{\text {CITATION }}},
\end{gathered}
$$

where $k_{\text {Clean }}^{\text {CITATION }}$ and $k_{\text {Rod }}^{\text {CITATION }}$ indicate the effective multiplication factors in the super-critical and subcritical cores, respectively.

Of the two numerical values by CITATION and MCNP, as mentioned in Sect. 8.2.2.1, the CITATION calculations needed to conduct a series of sensitivity and uncertainty analyses by SAGEP and UNCERTAINTY, respectively. Meanwhile, the MCNP calculations were requisite to assess the precision of eigenvalue calculations, such as eigenvalue bias [12]. That is why two numerical values were introduced by the stochastic (Eqs. (8.3) and (8.4)) and the deterministic (Eqs. (8.5) and (8.6)) approaches, and compared differently with the experimental values shown in Eqs. (8.1) and (8.2).

\subsubsection{Sensitivity Coefficient}

Sensitivity coefficient $S$ of the integral reactor physics parameter (effective multiplication factor) $R$ is defined by the ratio of the rate of change in $R$ and a certain parameter $x$ as follows:

$$
S=\frac{d R}{R} / \frac{d x}{x}
$$

The effective multiplication factor $k_{\text {eff }}$ is expressed by a balance equation of neutrons as follows:

$$
\mathbf{A} \phi=\frac{1}{k_{\mathrm{eff}}} \mathbf{F} \phi,
$$


where $\mathbf{A}$ and $\mathbf{F}$ indicate operators of transport and fission terms, respectively, and $\phi$ the forward neutron flux. Multiplying Eq. (8.8) by adjoint neutron flux $\phi^{*}$ and integrating over whole volume and energy, the following equation is obtained:

$$
\frac{1}{k_{\mathrm{eff}}}=\frac{\left\langle\phi^{*} \mathbf{A} \phi\right\rangle}{\left\langle\phi^{*} \mathbf{F} \phi\right\rangle},
$$

where brackets $<>$ indicate integration over the whole volume and energy.

With the use of an operator $\mathbf{B}$, Eq. (8.8) is expressed as follows:

$$
\left(\mathbf{A}-\frac{1}{k_{\mathrm{eff}}} \mathbf{F}\right) \phi=\mathbf{B} \phi=0 .
$$

Here, assuming that parameter $x$, operator $\mathbf{B}$, and neutron flux $\phi$ are changed into $x+\delta x, \mathbf{B}+\delta \mathbf{B}$, and $\phi+\delta \phi$, respectively, in a critical state, the following equations are obtained:

$$
(\mathbf{B}+\delta \mathbf{B})(\phi+\delta \phi)=0 \text {. }
$$

Neglecting second-order perturbation terms, Eq. (8.10) is expressed as follows:

$$
\mathbf{B} \delta \phi+\delta \mathbf{B} \phi=0 \text {. }
$$

Introducing the generalized adjoint flux $\Gamma^{*}$, the following equation is obtained with the use of adjoint operator $\mathbf{B}^{*}$ and a certain adjoint source term $q^{*}$, defined as reactivity in these analyses:

$$
\mathbf{B}^{*} \Gamma^{*}=q^{*} \text {. }
$$

Considering the theoretical background [13-16] and using Eqs. (8.10) through (8.13), the sensitivity coefficient in Eq. (8.7) is finally expressed by applying the first-order perturbation approximation [17], as follows:

$$
S=\frac{\left\langle\phi^{*}\left(-\frac{\partial \mathbf{B}}{\partial x}\right) \phi\right\rangle}{\left\langle\phi^{*} \mathbf{F} \phi\right\rangle} k_{e f f} .
$$

Finally, applicability of sensitivity analyses to $k_{\mathrm{eff}}$ was investigated for a thermal spectrum core, such as the KUCA core, with the use of SAGEP that had been originally developed for conducting the sensitivity analyses of fast reactors.

\subsubsection{Uncertainty}

In analyzing the cross-section uncertainty of nuclear data [18], the uncertainty of reactor physics parameter $v$ is expressed as follows: 
$v=\mathbf{G}_{t a r} \mathbf{M}\left(\mathbf{G}_{t a r}\right)^{\mathbf{t}}=\sum_{i} \sum_{j} s_{i} c_{i, j} s_{j} \equiv \sum_{i} \sum_{j} v_{i, j} \quad(1 \leq i, j \leq p)$

where $\mathbf{G}_{t a r}(1 \times p)$ indicates the sensitivity vector of reactor physics parameters, $\mathbf{M}(p \times p)$ the covariance matrix of nuclear reaction parameters, $s_{i}$ the sensitivity coefficient, $c_{i, j}$ the covariance, $v_{i, j}$ the factor of uncertainty and $p$ the number of nuclear reactions including the nuclides. Thus, the contribution of uncertainty $u_{i}$ in each nuclear reaction can be defined as follows:

$$
u_{i} \equiv \sum_{i} v_{i, j}
$$

Generally, since sensitivity coefficient $s_{i}$ and covariance $c_{i, j}$ are dominant in the energy group, the factor of uncertainty is finally expressed with the use of the maximum number of energy group $G$ as follows:

$$
v_{i, j}=\sum_{g} \sum_{g^{\prime}} s_{g}^{i} c_{g, g^{\prime}}^{i, j} s_{g^{\prime}}^{j}\left(1 \leq g, g^{\prime} \leq G\right),
$$

where $g$ and $g^{\prime}$ indicate the energy groups.

\subsubsection{Results and Discussion}

\subsubsection{Eigenvalue Calculations}

In MCNP simulations, excess reactivity and control rod worth were obtained by two eigenvalue calculations in critical and super-critical, and, critical and subcritical states, respectively: the difference between the inverse values of eigenvalue calculations in the two states. Here, MCNP eigenvalue calculations were made with 2,000 active cycles of 50,000 histories, resulting in a standard deviation within 10 $\mathrm{pcm}$. The numerical results of excess reactivity and control rod worth were obtained by MCNP6.1 with JENDL-4.0 in EE1 and E3 cores, as shown in Table 8.3a, b, respectively. Moreover, estimation of $\mathrm{C} / \mathrm{E}$ (calculation/experiment) values revealed an accuracy of around 5\% error with the use of the experimental and numerical results of excess reactivity and control rod worth, as shown in Eqs. (8.1) and (8.2), respectively, excluding small values of excess reactivity and $\mathrm{C} 2$ control rod worth in EE1 core. From the calculated results in Table 8.3a, b, the difference between numerical analyses by MCNP6.1 with JENDL-4.0 and ENDF/B-VII.0 was found within an error of $3 \%$ of the $\mathrm{C} / \mathrm{E}$ value.

The ability of MCNP6.1 calculations was confirmed at a critical state in terms of the eigenvalue bias by the MCNP approach, as shown in Table 8.4. In EE1 core, eigenvalue bias by MCNP6.1 with JENDL-4.0 demonstrated a relatively small value 
Table 8.3 Comparison between measured and calculated (MCNP6.1) results of excess reactivity and control rod worth in EE1 and E3 cores (Ref. [1])

(a) EE1

\begin{tabular}{l|l|l|l}
\hline Reactivity & Exp. $[\mathrm{pcm}]$ & Cal. $[\mathrm{pcm}](\mathrm{C} / \mathrm{E}$ value $)$ & \\
\cline { 3 - 4 } & & JENDL-4.0 & ENDF/B-VII.0 \\
\hline Excess & $210 \pm 6$ & $198 \pm 18(0.94 \pm 0.09)$ & $196 \pm 18(0.93 \pm 0.09)$ \\
\hline C1 rod & $838 \pm 11$ & $857 \pm 18(1.02 \pm 0.02)$ & $843 \pm 18(1.01 \pm 0.02)$ \\
\hline C2 rod & $144 \pm 3$ & $134 \pm 18(0.93 \pm 0.13)$ & $135 \pm 18(0.94 \pm 0.13)$ \\
\hline C3 rod & $521 \pm 8$ & $500 \pm 18(0.96 \pm 0.04)$ & $491 \pm 18(0.94 \pm 0.04)$ \\
\hline
\end{tabular}

(b) E3

\begin{tabular}{l|l|l|l}
\hline \multirow{2}{*}{ Reactivity } & Exp. $[\mathrm{pcm}]$ & Cal. $[\mathrm{pcm}](\mathrm{C} / \mathrm{E}$ value $)$ & \multicolumn{2}{l}{} \\
\cline { 3 - 4 } & & JENDL-4.0 & ENDF/B-VII.0 \\
\hline Excess & $264 \pm 2$ & $246 \pm 16(0.93 \pm 0.06)$ & $241 \pm 16(0.91 \pm 0.06)$ \\
\hline C1 rod & $551 \pm 6$ & $526 \pm 16(0.95 \pm 0.03)$ & $536 \pm 16(0.97 \pm 0.03)$ \\
\hline C2 rod & $429 \pm 4$ & $400 \pm 16(0.93 \pm 0.04)$ & $388 \pm 16(0.90 \pm 0.04)$ \\
\hline C3 rod & $329 \pm 4$ & $314 \pm 16(0.95 \pm 0.05)$ & $315 \pm 16(0.96 \pm 0.05)$ \\
\hline
\end{tabular}

Table 8.4 Numerical results by MCNP6.1 eigenvalue calculations in critical state (Ref. [1])

\begin{tabular}{l|l|l|l}
\hline EE1 & E3 \\
\hline JENDL-4.0 & ENDF/B-VII.0 & JENDL-4.0 & ENDF/B-VII.0 \\
\hline $1.00246 \pm 0.00009$ & $1.00461 \pm 0.00009$ & $1.00443 \pm 0.00008$ & $1.00578 \pm 0.00008$ \\
\hline
\end{tabular}

of about $250 \mathrm{pcm}$, and with ENDF/B-VII.0 a value about $460 \mathrm{pcm}$ (Table 8.4). Similarly, in E3 core, the value with JENDL-4.0 was small, about $440 \mathrm{pcm}$, compared with that with ENDF/B-VII.0, about $580 \mathrm{pcm}$. From the analyses of eigenvalue bias, a significant index of the accuracy of experimental analyses was acquired by MCNP calculations in EE1 and E3 cores at KUCA; also, as in previous studies [12, 19], JENDL-4.0 was considered reliable as a reference nuclear data library in a series of sensitivity and uncertainty analyses of excess reactivity and control rod worth in the KUCA A core.

The numerical values of $k_{\text {eff }}$ in excess reactivity and control rod worth shown in Eqs. (8.5) and (8.6), respectively, were deduced, for a clean core (withdrawal of all control and safety rods) and a subcritical core (control rod insertion) in super-critical and subcritical states, respectively, through the results of diffusion-based eigenvalue calculations (CITATION) in the 107-energy-group and $x-y-z$ dimensions (3-D) with JENDL-4.0. Also, on the basis of accuracy of experimental analyses by CITATION (Table 8.5), sensitivity analyses of $k_{\text {eff }}$ in excess reactivity and control rod worth were notably conducted by diffusion-based calculations (SAGEP). 
Table 8.5 Comparison between measured and calculated (CITATION with JENDL-4.0) results of $k_{\text {eff }}$ (excess reactivity: super-critical state; control rod worth: subcritical state) in EE1 and E3 cores (Ref. [1])

\begin{tabular}{l|l|l|l|l}
\hline \multirow{2}{*}{ Reactivity } & \multicolumn{2}{|l|}{ EE1 } & E3 \\
\cline { 2 - 5 } & Experiment & Calculation & Experiment & Calculation \\
\hline Excess & 1.00210 & 1.00030 & 1.00265 & 1.00067 \\
\hline C1 rod & 0.99169 & 0.99525 & 0.99452 & 0.99513 \\
\hline C2 rod & 0.99856 & 0.99903 & 0.99573 & 0.99673 \\
\hline C3 rod & 0.99482 & 0.99447 & 0.99672 & 0.99762 \\
\hline
\end{tabular}

\subsubsection{Sensitivity Coefficients}

Sensitivity coefficients Eq. (8.7) of $k_{\text {eff }}$ in excess reactivity and control rod worth were analyzed by the SAGEP code for assessing cross-section data of inelastic scattering, elastic scattering and capture reactions of ${ }^{27} \mathrm{Al}$, boron isotopes $\left({ }^{10,11} \mathrm{~B}\right)$, carbon $\left({ }^{12} \mathrm{C}\right)$, hydrogen $\left({ }^{1} \mathrm{H}\right)$, oxygen $\left({ }^{16} \mathrm{O}\right)$, and uranium isotopes $\left({ }^{234,235,236,238} \mathrm{U}\right)$ comprising the core components.

For excess reactivities in EE1 and E3 cores, the sensitivity coefficients of elastic scattering reactions were relatively highly positive, mostly $1 \mathrm{MeV}$, in ${ }^{27} \mathrm{Al},{ }^{12} \mathrm{C}$, and ${ }^{1} \mathrm{H}$, as shown in Fig. 8.4a, and b, respectively. Sensitivity coefficients were dominant over the high-energy $(\mathrm{MeV})$ region of the inelastic scattering reactions of ${ }^{27} \mathrm{Al}$ in $k_{\text {eff }}$ (excess reactivities) at EE1 and E3 cores shown in Fig. 8.5a, b, respectively. In thermal neutron region shown in Fig. 8.6a, b, the capture cross sections of ${ }^{27} \mathrm{Al},{ }^{1} \mathrm{H}$, and ${ }^{235} \mathrm{U}$ were highly sensitive at EE1 and E3 cores, respectively. Also, the sensitivity coefficients of ${ }^{27} \mathrm{Al},{ }^{1} \mathrm{H}$, and ${ }^{235} \mathrm{U}$ were remarkably higher in E3 core than in EE1 core ranging between 0.01 and $100 \mathrm{eV}$ shown in Fig. 8.6b, because E3 core is a relatively soft-spectrum core shown in Fig. 8.3. In a series of sensitivity analyses shown in Figs. 8.4 through 8.6, effects of Al on sensitivities were observed in entire reactions and energy regions, and attributable to containing $\mathrm{Al}$ itself comprising of $\mathrm{U}-\mathrm{Al}$ alloy (HEU) fuel plates and $\mathrm{Al}$ sheath of fuel assembly.

Further study of the sensitivity coefficients was made of $k_{\text {eff }}$ (worth of $\mathrm{C} 1$ control rod) at EE1 and E3 cores, since the worth of $\mathrm{C} 1$ control rod was mostly larger in both EE1 and E3 cores, compared with other reactivities shown in Table 8.3. Also, the worth of $\mathrm{C} 1$ control rod was selected to investigate directly the effect of the boron isotope component of the control rod. As shown in Fig. 8.7a, b, the sensitivity coefficients of ${ }^{27} \mathrm{Al},{ }^{10} \mathrm{~B},{ }^{1} \mathrm{H}$, and ${ }^{235} \mathrm{U}$ were negative in the capture reactions; among these, the capture cross sections of ${ }^{27} \mathrm{Al}$ and ${ }^{235} \mathrm{U}$ were highly sensitive in the thermal neutron region, as well as for capture reactions in the excess reactivity shown in Fig. 8.6a, b. Moreover, the sensitivity coefficient of ${ }^{27} \mathrm{Al}$ was remarkably large in the E3 core with a thermal neutron spectrum, as shown in Fig. 8.7b, as was that of ${ }^{235} \mathrm{U}$. Finally, in $\mathrm{C} 1$ control rod worth, sensitivity coefficient of ${ }^{10} \mathrm{~B}$ was found relatively of negligible significance due to an insertion of $\mathrm{C} 1$ control rod, although that of ${ }^{27} \mathrm{Al}$ comprising of core components (U-Al alloy fuel plates and $\mathrm{Al}$ sheath) was large. 


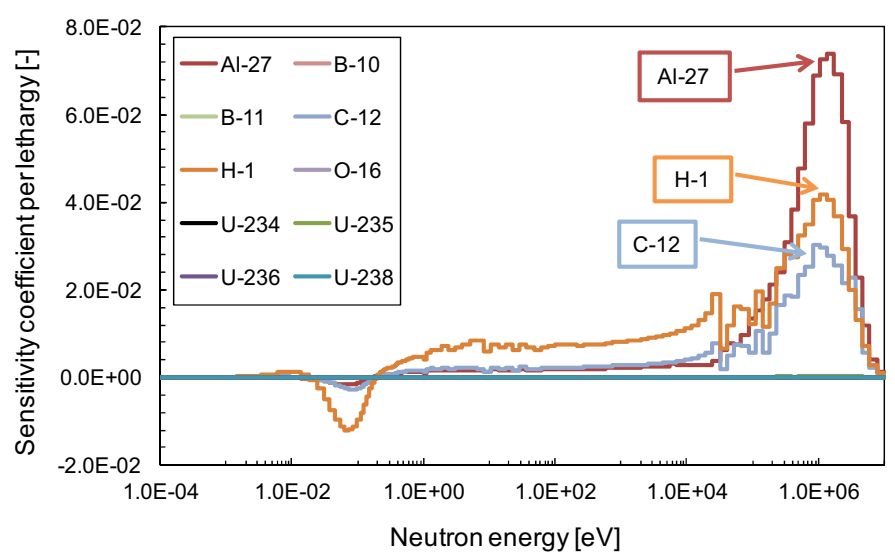

(a) EE1 core

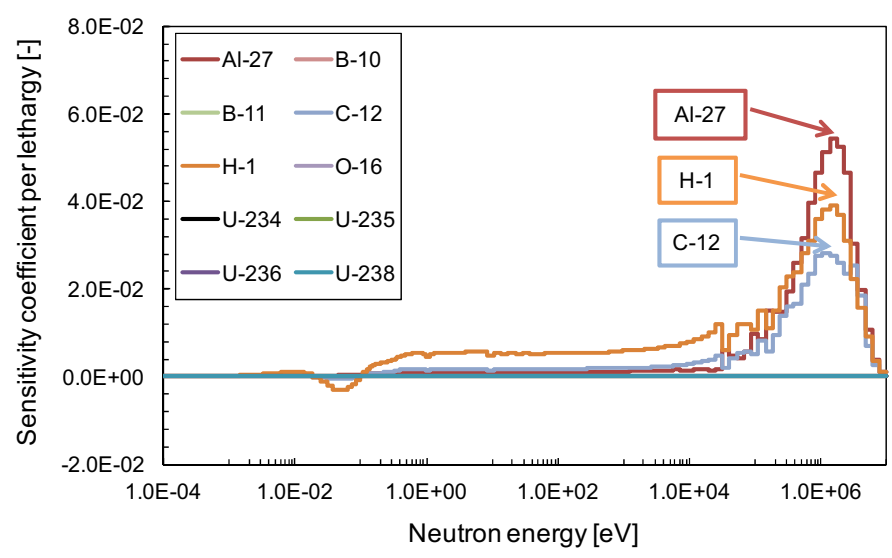

(b) E3 core

Fig. 8.4 Sensitivity coefficients for elastic scattering reactions in excess reactivity (Ref. [1])

\subsubsection{Uncertainty}

The uncertainty analyses by the UNCERTAINTY code of the MARBLE system were conducted with the use of JENDL-4.0 covariance data (107-energy-group). Since the covariance data of ${ }^{27} \mathrm{Al},{ }^{12} \mathrm{C}$, and ${ }^{1} \mathrm{H}$ isotopes consisted mainly of core components that are not contained in JENDL-4.0, uncertainty analyses were executed for various reactions of ${ }^{10,11} \mathrm{~B},{ }^{16} \mathrm{O}$, and ${ }^{235,238} \mathrm{U}$ isotopes comprising of control and fuel rods in the KUCA A-core, including capture, elastic scattering, inelastic scattering, fission, and $(n, 2 n)$ reactions covered in the SAGEP code. As shown in Table 8.6, the uncertainty of excess reactivity in EE1 core induced by covariance data was large, total uncertainty $135.8 \mathrm{pcm}$, compared with an experimental error of $6 \mathrm{pcm}$ (Table 8.2). The value of total uncertainty was acquired through the square root of the sum of squares for reaction-wise contributions. Among the isotopes, uncertainty was 


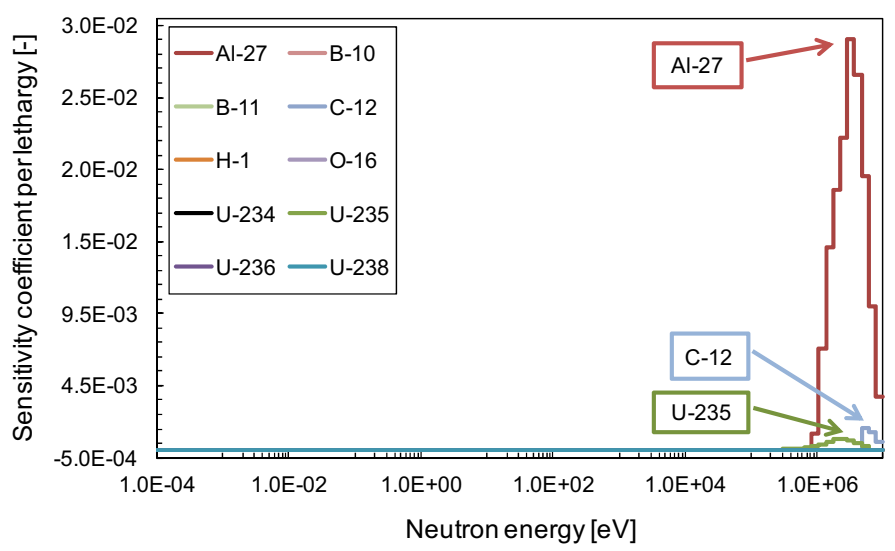

(a) EE1 core

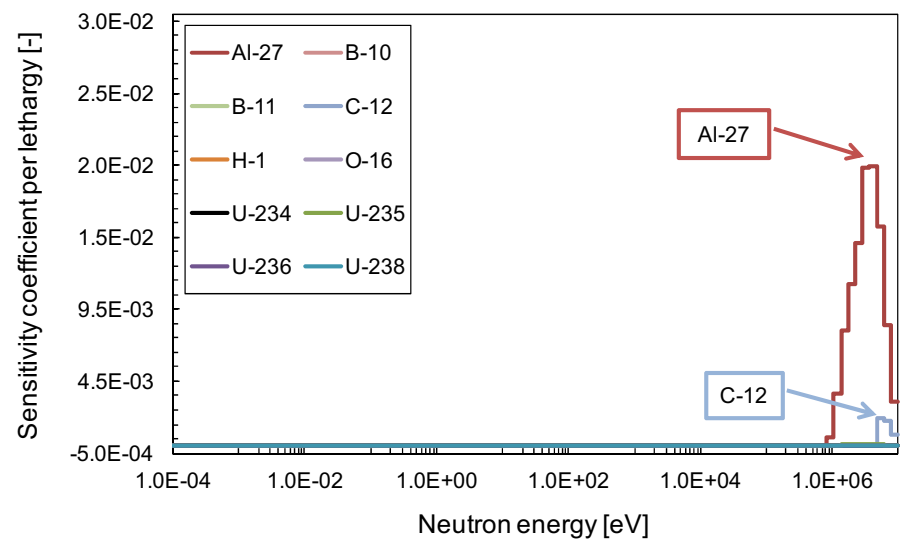

(b) E3 core

Fig. 8.5 Sensitivity coefficients for inelastic scattering reactions in excess reactivity (Ref. [1])

dominant over the sum of all contributions, including the capture and fission reactions of ${ }^{235} \mathrm{U}$; a large contribution [19] was attributable to the sensitivity coefficients of ${ }^{235} \mathrm{U}$ capture and fission reactions. For the worth of $\mathrm{C} 1$ control rod in $\mathrm{E} 3$ core, the total uncertainty was $164.1 \mathrm{pcm}$, although the reaction-wise contribution was slight in the boron isotopes, as shown in Table 8.7, demonstrating the same tendency of excess reactivity as in EE1 core shown in Table 8.6. Finally, the uncertainty of $k_{\text {eff }}$ in excess reactivity and control rod worth $(\mathrm{C} 1, \mathrm{C} 2$ and $\mathrm{C} 3$ rods) was summarized around $150 \mathrm{pcm}$ in the EE1 and E3 cores.

Furthermore, the effect of decreasing uncertainty induced by nuclear data on calculated $k_{\text {eff }}$ was investigated by the cross-section adjustment method [20,21], with the use of uncertainty of $k_{\text {eff }}$ values. The result of this investigation demonstrated a great improvement from around 150 to $3 \mathrm{pcm}$ induced by nuclear data of JENDL4.0 in all excess reactivity and control rod worth in EE1 and E3 cores. Moreover, by 


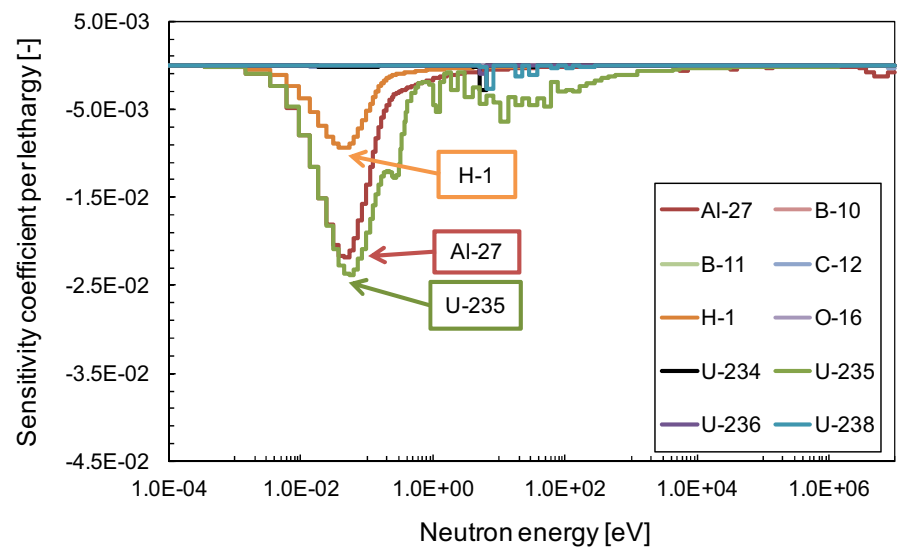

(a) EE1 core

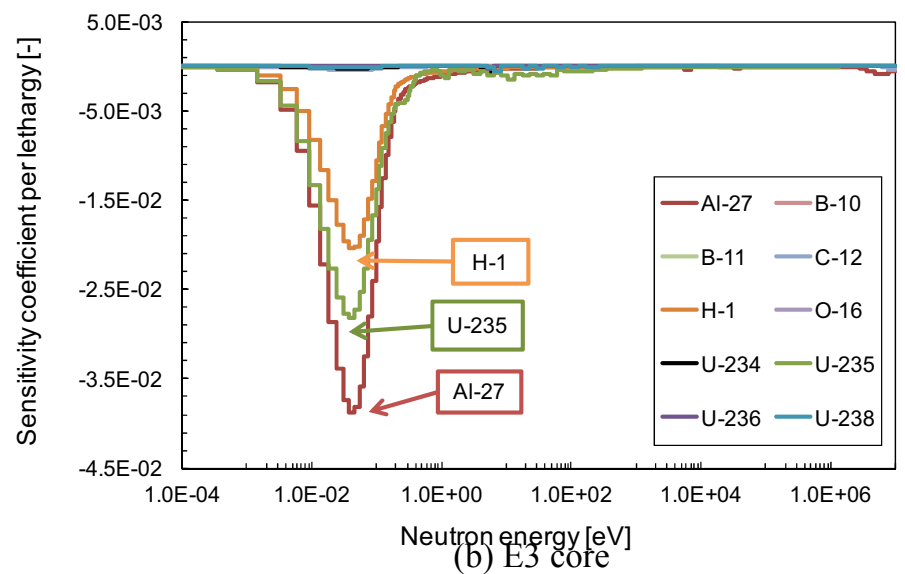

Fig. 8.6 Sensitivity coefficients for capture reactions in excess reactivity (Ref. [1])

applying the cross-section adjustment method to the uncertainty analyses, the $\mathrm{C} / \mathrm{E}$ value of all excess reactivity and control rod worth in both EE1 and E3 cores reached around a unit. 


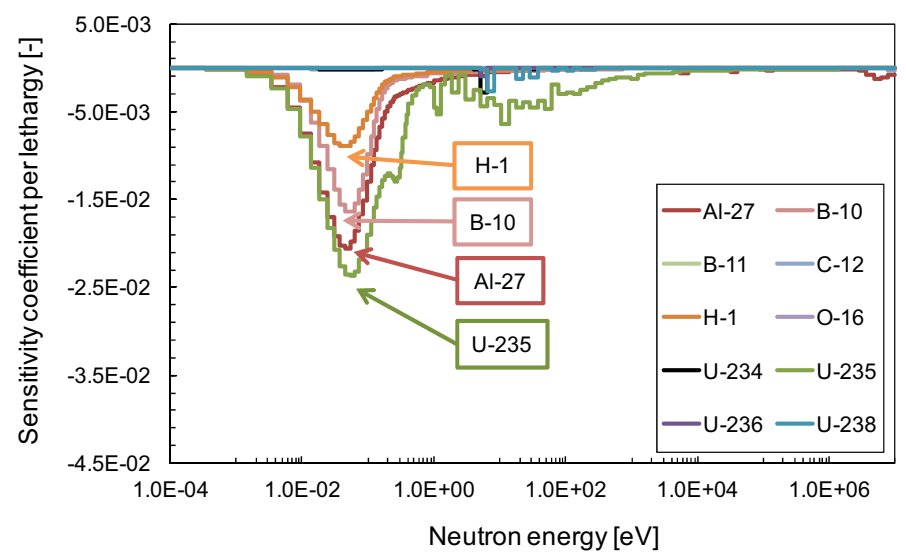

(a) EE1 core

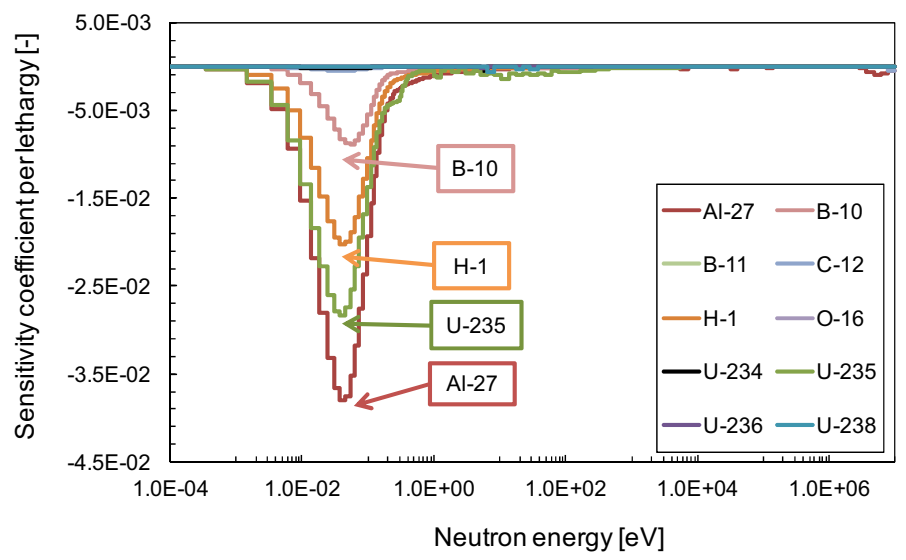

(b) E3 core

Fig. 8.7 Sensitivity coefficients for capture reactions in C1 rod worth (Ref. [1])

Table 8.6 Reaction-wise contribution [pcm] to excess reactivity induced by covariance data of JENDL-4.0 in EE1 core (Ref. [1])

\begin{tabular}{l|c|l|l|l|l|c}
\hline \multirow{2}{*}{ Isotopes } & \multicolumn{6}{l}{ Reactions } \\
\cline { 2 - 7 } & Capture & Elastic & Inelastic & Fission & $(n, 2 n)$ & Total \\
\hline${ }^{10} \mathrm{~B}$ & 0.0 & 0.0 & - & - & - & 0.0 \\
\hline${ }^{11} \mathrm{~B}$ & 0.0 & 0.0 & - & - & - & 0.0 \\
\hline${ }^{16} \mathrm{O}$ & 0.0 & 0.0 & 0.0 & - & 0.0 & 0.0 \\
\hline${ }^{235} \mathrm{U}$ & 111.7 & 5.3 & 12.9 & 44.7 & 0.7 & 121.1 \\
\hline${ }^{238} \mathrm{U}$ & 2.8 & 0.2 & 0.9 & 0.1 & 0.1 & 2.9 \\
\hline & & & & & Total & 135.8 \\
\hline
\end{tabular}


Table 8.7 Reaction-wise contribution [pcm] to the worth of $\mathrm{C} 1$ control rod induced by covariance data of JENDL-4.0 in E3 core (Ref. [1])

\begin{tabular}{l|c|l|l|l|l|c}
\hline \multirow{2}{*}{ Isotopes } & \multicolumn{6}{l}{ Reactions } \\
\cline { 2 - 7 } & Capture & Elastic & Inelastic & Fission & $(n, 2 n)$ & Total \\
\hline${ }^{10} \mathrm{~B}$ & 9.0 & 0.0 & - & - & - & 9.0 \\
\hline${ }^{11} \mathrm{~B}$ & 0.0 & 4.4 & - & - & - & 4.4 \\
\hline${ }^{16} \mathrm{O}$ & 0.0 & 1.2 & 0.0 & - & 0.0 & 1.2 \\
\hline${ }^{235} \mathrm{U}$ & 113.0 & 1.1 & 2.8 & 81.8 & 0.2 & 139.5 \\
\hline${ }^{238} \mathrm{U}$ & 0.7 & 0.1 & 0.2 & 0.0 & 0.0 & 0.8 \\
\hline & & & & & Total & 164.1 \\
\hline
\end{tabular}

\subsection{Benchmarks}

\subsubsection{Experimental Analyses}

\subsubsection{Reactivity Measurements}

Before quantifying the uncertainty in criticality, the validity of the standard modeling of the core configuration was verified by the comparison of the excess reactivity and the control rod worth between the calculation and the experiment, without consideration of variation in the position and material property. The calculation of the reactivity was performed through two eigenvalue calculations with MCNP6.1 and KENO-VI module of SCALE6.2 code system [22] together with ENDF/B-VII.1. The calculated reactivity was obtained as follows:

$$
\begin{aligned}
\rho_{\mathrm{excess}}^{\mathrm{cal}} & =\frac{1}{k_{\mathrm{eff}}^{\text {critical }}}-\frac{1}{k_{\mathrm{eff}}^{\text {clean }}}, \\
\rho_{\mathrm{rod}}^{\mathrm{cal}} & =\frac{1}{k_{\mathrm{eff}}^{\text {rod }}}-\frac{1}{k_{\mathrm{eff}}^{\text {critical }}},
\end{aligned}
$$

where $\rho_{\text {excess }}^{\text {cal }}$ and $\rho_{\text {rod }}^{\text {cal }}$ are the calculated excess reactivity and control rod worth, respectively, $k_{\text {eff }}^{\text {critical }}$ the $k_{\text {eff }}$ value at the critical state, $k_{\text {eff }}^{\text {clean }}$ the $k_{\text {eff }}$ value at the withdrawal of all control rods and $k_{\text {eff }}^{\text {rod }}$ the $k_{\text {eff }}$ value at the insertion of control rod $\mathrm{C} 1, \mathrm{C} 2$, or $\mathrm{C} 3$ in the critical state.

\subsubsection{Numerical Simulations}

Through the development of the methodology of the adjoint flux [23, 24], sensitivity and uncertainty analyses were easily conducted with the use of the Monte Carlo method applying to rigorous modeling without homogenization [25]. Sensitivity and 
uncertainty analyses of $k_{\text {eff }}$ induced by nuclear data were performed by TSUNAMI3D module of SCALE6.2 together with ENDF/B-VII.1 and its 56-group covariance library (56groupcov7.1) for standard modeling of EE1 and E3 core configurations. Here, the adjoint flux was obtained by the CLUTCH method [26].

Variation in the manufacturing tolerance of HEU plates is provided by statistically processing the measured results (enrichment and thickness) of all plates at KUCA and with specification sheet in the fabrication for length of each side, as shown in Table 8.1. On the basis of the variation in HEU plates, the uncertainty analyses for the enrichment and tolerance of length of both sides were conducted with KPERT option in MCNP6.1 together with ENDF/B-VII.1. Since the variation is too small to explicitly calculate the impact (difference in $k_{\text {eff }}$ values), a pseudo variation was considered $10 \%$, instead of the actual variation shown in Table 8.1, in the perturbation for the enrichment and length of sides of the HEU plates. Here, while varying the length of the sides of HEU plates, their mass was maintained by retaining the original number of atoms. The pseudo uncertainty of $k_{\text {eff }}$ attributed to varying the enrichment and length was converted to the actual one (Table 8.1) on the basis of the standard method provided in the guideline by OECD/NEA [27] as follows:

$$
\Delta k_{\mathrm{eff}}=\sqrt{\sum_{i=1}^{N} \frac{1}{n_{i}}\left(\frac{\Delta k_{\mathrm{eff}, i}}{\Delta q_{i}} \cdot \frac{\Delta q_{i}}{\Delta x_{i}}\right)^{2}}
$$

where, $\Delta k_{\text {eff }}$ is the difference between $k_{\text {eff }}$ values before and after variation $\Delta q_{i}$ (the intensity of the pseudo variation), $\Delta x_{\mathrm{i}}$ the real uncertainty shown in Table 8.1, $n_{i}$ the number of HEU plates involved in the variation, finally, $i$ and $N$ the region of perturbation and the total number of regions, respectively. In the calculation for the variation in the enrichment and the length of HEU plates, the core was divided into fuel rod regions in the $x-y$ plane (25 divisions in EE1 core; 21 divisions in E3 core) and into three regions in $z$ axis $(N=75$ and 63 in EE1 and E3 cores, respectively). The uncertainty of $k_{\text {eff }}$ by varying the thickness of HEU plates was evaluated by setting all HEU plates 3.1\% decreasing in thickness according to Ref. [14].

The uncertainty attributed to the reproducibility of control rod position was approximately evaluated by eigenvalue calculations (Eq. (8.20)) with MCNP6.1, and by varying control rod position ( $x-y$ directions) in the casing for $5.15 \mathrm{~mm}$ radially ( $\Delta q_{i}$ in Eq. (8.20)) and by 8 segments circumferentially. Then, the actual uncertainty of control rod position in the $x-y$ plane is limited to a radius of $1.15 \mathrm{~mm}\left(\Delta x_{i}\right.$ in Eq. (8.20)). In the case of one (two) control rod(s) inserted, $N$ in Eq. (8.20) becomes 8 (64). The uncertainty was finally deduced by subtracting the $k_{\text {eff }}$ value obtained at the reference position from that obtained by varying the position. 


\subsubsection{Uncertainty}

\subsubsection{Eigenvalue Bias}

The eigenvalue calculations with the use of MCNP6.1 and SCALE code system were performed for a total of $1 \mathrm{E}+08$ histories $(1 \mathrm{E}+03$ active cycles of $1 \mathrm{E}+$ 05 each); the statistical error was less than $10 \mathrm{pcm}$. Through the comparison of the results of $k_{\text {eff }}$ between MCNP6.1 and SCALE6.2/KENO-VI, the difference was found about $100 \mathrm{pcm}$ in EE1 core and about $200 \mathrm{pcm}$ in E3 core, as shown in Tables 8.8 and 8.9, respectively. Moreover, eigenvalue bias was dependent on the neutron spectrum of the core: about $350 \mathrm{pcm}$ and about $600 \mathrm{pcm}$ in EE1 and E3 cores, respectively. Interestingly, the uncertainty induced by nuclear data showed about $950 \mathrm{pcm}$ in the $k_{\text {eff }}$ evaluation by the SCALE code. Also, the uncertainty was found almost same value regardless of the control rod position, indicating that the neutronic characteristics are the same even at insertion and withdrawal of control rods.

To validate the modeling of core configuration and eigenvalue calculations, the calculated results of excess reactivity and control rod worth compared with the measured ones in EE1 and E3 cores, as shown in Tables 8.10 and 8.11, respectively. Although eigenvalue bias was smaller than the uncertainty induced by nuclear

Table 8.8 Comparison of $k_{\text {eff }}$ values between experiments and calculations (MCNP6.1 and SCALE6.2) in EE1 core (Ref. [2])

\begin{tabular}{|c|c|c|c|c|c|}
\hline \multirow[t]{2}{*}{ Case } & \multirow[t]{2}{*}{ Core } & \multirow{2}{*}{$\begin{array}{l}\text { Inserted } \\
\text { control rod } \\
\text { (position) }\end{array}$} & \multicolumn{3}{|c|}{ Effective multiplication factor $k_{\text {eff }}$} \\
\hline & & & Experiment & MCNP6.1 & SCALE6.2 \\
\hline $\mathrm{I}-1$ & EE1 & - & $1.00202 \pm 0.00006$ & $1.00534 \pm 0.00009$ & $\begin{array}{l}1.00574 \pm 0.00009 \\
(947.7 \pm 0.3 \mathrm{pcm})^{*}\end{array}$ \\
\hline $\mathrm{I}-2$ & EE1 & $\begin{array}{l}\mathrm{C} 1 \text { (critical } \\
\text { position) }\end{array}$ & 1.00000 & $1.00348 \pm 0.00009$ & $\begin{array}{l}1.00395 \pm 0.00010 \\
(948.3 \pm 0.3 \mathrm{pcm})\end{array}$ \\
\hline I-3 & EE1 & $\begin{array}{l}\mathrm{C} 3 \text { (critical } \\
\text { position) }\end{array}$ & 1.00000 & $1.00374 \pm 0.00009$ & $\begin{array}{l}1.00383 \pm 0.00010 \\
(949.0 \pm 0.3 \mathrm{pcm})\end{array}$ \\
\hline $\mathrm{I}-4$ & EE1 & $\begin{array}{l}\text { C3 (critical } \\
\text { position) } \\
\text { C1 (full } \\
\text { inserted) }\end{array}$ & $0.99199 \pm 0.00001$ & $0.99651 \pm 0.00009$ & $\begin{array}{l}0.99533 \pm 0.00010 \\
(956.5 \pm 0.3 \mathrm{pcm})\end{array}$ \\
\hline I-5 & EE1 & $\begin{array}{l}\text { C3 (critical } \\
\text { position) } \\
\text { C2 (full } \\
\text { inserted) }\end{array}$ & $0.99861 \pm 0.00002$ & $1.00359 \pm 0.00009$ & $\begin{array}{l}1.00242 \pm 0.00010 \\
(949.7 \pm 0.3 \mathrm{pcm})\end{array}$ \\
\hline I-6 & EE1 & $\begin{array}{l}\text { C1 (critical } \\
\text { position) } \\
\text { C3 (full } \\
\text { inserted) }\end{array}$ & $0.99501 \pm 0.00008$ & $1.00002 \pm 0.00009$ & $\begin{array}{l}0.99899 \pm 0.00010 \\
(953.7 \pm 0.3 \mathrm{pcm})\end{array}$ \\
\hline
\end{tabular}

*Uncertainty by SCALEW6.2/TSUNAMI-3D 
Table 8.9 Comparison of $k_{\text {eff }}$ values between experiments and calculations (MCNP6.1 and SCALE6.2) in E3 core (Ref. [2])

\begin{tabular}{|c|c|c|c|c|c|}
\hline \multirow[t]{2}{*}{ Case } & \multirow[t]{2}{*}{ Core } & \multirow{2}{*}{$\begin{array}{l}\text { Inserted } \\
\text { control rod } \\
\text { (position) }\end{array}$} & \multicolumn{3}{|c|}{ Effective multiplication factor $k_{\text {eff }}$} \\
\hline & & & Experiment & MCNP6.1 & SCALE6.2 \\
\hline II-1 & E3 & - & $1.00253 \pm 0.00002$ & $1.00823 \pm 0.00008$ & $\begin{array}{l}1.01045 \pm 0.00009 \\
(911.7 \pm 0.3 \mathrm{pcm})^{*}\end{array}$ \\
\hline II-2 & E3 & $\begin{array}{l}\mathrm{C} 1 \text { (critical } \\
\text { position) }\end{array}$ & 1.00000 & $1.00578 \pm 0.00008$ & $\begin{array}{l}1.00811 \pm 0.00009 \\
(912.6 \pm 0.3 \mathrm{pcm})\end{array}$ \\
\hline II-3 & E3 & $\begin{array}{l}\mathrm{C} 2 \text { (critical } \\
\text { position) }\end{array}$ & 1.00000 & $1.00614 \pm 0.00008$ & $\begin{array}{l}1.00820 \pm 0.00009 \\
(913.4 \pm 0.3 \mathrm{pcm})\end{array}$ \\
\hline II-4 & E3 & $\begin{array}{l}\text { C2 (critical } \\
\text { position) } \\
\text { C1 (full } \\
\text { inserted) }\end{array}$ & $0.99477 \pm 0.00006$ & $1.00275 \pm 0.00008$ & $\begin{array}{l}1.00312 \pm 0.00009 \\
(918.6 \pm 0.3 \mathrm{pcm})\end{array}$ \\
\hline II-5 & E3 & $\begin{array}{l}\text { C1 (critical } \\
\text { position) } \\
\text { C2 (full } \\
\text { inserted) }\end{array}$ & $0.99592 \pm 0.00004$ & $1.00212 \pm 0.00008$ & $\begin{array}{l}1.00396 \pm 0.00009 \\
(918.0 \pm 0.3 \mathrm{pcm})\end{array}$ \\
\hline II-6 & E3 & $\begin{array}{l}\text { C1 (critical } \\
\text { position) } \\
\text { C3 (full } \\
\text { inserted) }\end{array}$ & $0.99687 \pm 0.00004$ & $1.00074 \pm 0.00008$ & $\begin{array}{l}1.00495 \pm 0.00010 \\
(916.3 \pm 0.3 \mathrm{pcm})\end{array}$ \\
\hline
\end{tabular}

*Uncertainty by SCALEW6.2/TSUNAMI-3D

Table 8.10 Comparison between measured and calculated reactivity at critical experiments in EE1 core (Ref. [2])

\begin{tabular}{l|l|l|l}
\hline Reactivity & Experiment $[\mathrm{pcm}]$ & MCNP6.1 $[\mathrm{pcm}]$ & SCALE6.2/KENO-VI [pcm] \\
\hline Excess & $202 \pm 6$ & $184 \pm 13$ & $189 \pm 19$ \\
& & $(0.91 \pm 0.07)$ & $(0.93 \pm 010)$ \\
\hline C1 rod & $807 \pm 11$ & $876 \pm 13$ & $862 \pm 14$ \\
& & $(1.09 \pm 0.02)$ & $(1.07 \pm 0.02)$ \\
\hline C2 rod & $139 \pm 3$ & $151 \pm 13$ & $152 \pm 14$ \\
& & $(1.09 \pm 0.09)$ & $(1.09 \pm 0.10)$ \\
\hline C3 rod & $502 \pm 8$ & $525 \pm 13$ & $494 \pm 14$ \\
& & $(1.05 \pm 0.03)$ & $(0.98 \pm 0.03)$ \\
\hline
\end{tabular}

(): C/E (calculation/experiment) value

data, the comparison revealed the relative difference of $10 \%$ in $\mathrm{C} / \mathrm{E}$ (calculation/experiment) values, indicating that the calculations of EE1 and E3 cores were valid and pertinently modeled for experimental analyses. 
Table 8.11 Comparison between measured and calculated reactivity at critical experiments in E3 core (Ref. [2])

\begin{tabular}{l|l|l|l}
\hline Reactivity & Experiment[pcm] & MCNP6.1 [pcm] & SCALE-6.2/KENO-VI [pcm] \\
\hline Excess & $252 \pm 2$ & $\begin{array}{l}242 \pm 11 \\
(0.96 \pm 0.04)\end{array}$ & $\begin{array}{l}229 \pm 13 \\
(0.91 \pm 0.05)\end{array}$ \\
\hline C1 rod & $526 \pm 6$ & $536 \pm 11$ & $502 \pm 13$ \\
& & $(1.02 \pm 0.02)$ & $(0.95 \pm 0.03)$ \\
\hline C2 rod & $410 \pm 4$ & $377 \pm 11$ & $410 \pm 13$ \\
& & $(0.92 \pm 0.03)$ & $(1.00 \pm 0.03)$ \\
\hline C3 rod & $314 \pm 4$ & $315 \pm 11$ & $312 \pm 13$ \\
& & $(1.04 \pm 0.04)$ & $(0.99 \pm 0.04)$ \\
\hline
\end{tabular}

(): $\mathrm{C} / \mathrm{E}$ (calculation/experiment) value

\subsubsection{Core Components}

The impact of ${ }^{235} \mathrm{U}$ was observed about a significant $900 \mathrm{pcm}$ in both EE1 and E3 cores, as shown in Tables 8.12 and 8.13, respectively. Especially, in the EE1 core, the uncertainty was mostly composed of the values of $\chi, v$ and $(n, \gamma)$ (capture cross section) reactions of ${ }^{235} \mathrm{U}$ that are related to the infinite multiplication factor. In fact, sensitivity profiles of the $\chi$ value of ${ }^{235} \mathrm{U}$ shown in Fig. 8.8 were large with a large number of standard deviations. A marked difference was observed in the $\bar{v}$ value of ${ }^{235} \mathrm{U}$ shown in Fig. 8.9 between EE1 and E3 cores at thermal neutron and resonance regions in sensitivity profiles; also, core spectrum dependence on sensitivity was effectively canceled by constant standard deviation at these regions.

The uncertainty of capture reactions of polyethylene with the consideration of the thermal scattering law $S(\alpha, \beta)$ (termed ${ }^{* 1} \mathrm{H}$ in Tables 8.12 and 8.13) was effective in E3 core more than scattering $\left({ }^{* 1} \mathrm{H}(n, n)\right)$ reactions caused by the soft spectrum core with a large number of moderators as indicated by sensitivity profiles in Figs. 8.10 and 8.11 .

Furthermore, the core spectrum was found to be dependent on the uncertainty of aluminum ( $\mathrm{Al}$ ) in the HEU plate (U-Al alloy) and aluminum in the core component (Al sheath) at KUCA indicated by "27 $\mathrm{Al}$ " and "**27 $\mathrm{Al}$," respectively, as shown in Figs. 8.12 and 8.13. In the EE1 core, elastic scattering and inelastic scattering $\left({ }^{27} \mathrm{Al}\right.$ $\left.\left(n, n^{\prime}\right)\right)$ reactions in HEU plates affected the uncertainty because of the large sensitivity at the fast neutron region as shown in Figs. 8.14 and 8.15, respectively. Also, at the hard spectrum core, elastic scattering reactions of the $\mathrm{Al}$ sheath indicated higher value than that of ${ }^{27} \mathrm{Al}$ in HEU plates. Here, uncertainty that is not varied by control rod insertion should be emphasized, because the impact of nuclear reactions related to boron are very small and not shown in Tables 8.12 and 8.13. Accordingly, the calculated results of excess reactivity and control rod worth were considered in good agreement with the measured ones within a $10 \%$ difference because the uncertainty of boron is not induced by control rod insertions. 
Table 8.12 Breakdown of the uncertainty [pcm] of $k_{\text {eff }}$ in nuclides and nuclear reactions in EE1 core (Ref. [2])

\begin{tabular}{|c|c|c|c|c|c|c|c|c|}
\hline \multirow[t]{2}{*}{ Component } & \multirow{2}{*}{\multicolumn{2}{|c|}{$\begin{array}{l}\text { Nuclides } \\
\text { reaction } \\
\text { versus } \\
\text { reaction }\end{array}$}} & \multicolumn{6}{|l|}{ Case } \\
\hline & & & \multirow{2}{*}{$\begin{array}{l}\text { I-1 } \\
770.86 \\
\pm 0.27\end{array}$} & \multirow{2}{*}{\begin{tabular}{|l|l|} 
I-2 \\
772.51 \\
\pm 0.27 \\
\end{tabular}} & \multirow{2}{*}{$\begin{array}{l}\text { I-3 } \\
772.28 \\
\pm 0.27\end{array}$} & \multirow{2}{*}{\begin{tabular}{|l|} 
I-4 \\
779.51 \\
\pm 0.28 \\
\end{tabular}} & \multirow{2}{*}{$\begin{array}{l}\text { I-5 } \\
773.71 \\
\pm 0.27\end{array}$} & \multirow{2}{*}{$\begin{array}{l}\text { I-6 } \\
777.73 \\
\pm 0.27\end{array}$} \\
\hline HEU & $\begin{array}{l}{ }^{235} \mathrm{U} \\
\chi\end{array}$ & $\begin{array}{l}{ }^{235} \mathrm{U} \\
\end{array}$ & & & & & & \\
\hline & $\begin{array}{l}{ }_{\bar{v}}^{235} \mathrm{U} \\
\bar{v}\end{array}$ & $\begin{array}{l}{ }^{235} \mathrm{U} \\
\bar{v}\end{array}$ & $\begin{array}{l}360.18 \\
\pm 0.01\end{array}$ & $\begin{array}{l}360.12 \\
\pm 0.01\end{array}$ & $\begin{array}{l}360.13 \\
\pm 0.01\end{array}$ & $\begin{array}{l}359.77 \\
\pm 0.01\end{array}$ & $\begin{array}{l}360.06 \\
\pm 0.01\end{array}$ & $\begin{array}{l}359.88 \\
\pm 0.01\end{array}$ \\
\hline & $\begin{array}{l}{ }^{235} \mathrm{U} \\
(n, \gamma)\end{array}$ & $\begin{array}{l}{ }^{235} \mathrm{U} \\
(n, \gamma)\end{array}$ & $\begin{array}{l}216.32 \\
\pm 0.01\end{array}$ & $\begin{array}{l}216.33 \\
\pm 0.01\end{array}$ & $\begin{array}{l}216.36 \\
\pm 0.01\end{array}$ & $\begin{array}{l}216.34 \\
\pm 0.01\end{array}$ & $\begin{array}{l}216.34 \\
\pm 0.01\end{array}$ & $\begin{array}{l}216.34 \\
\pm 0.01\end{array}$ \\
\hline & $\begin{array}{l}{ }^{235} \mathrm{U} \\
(n, f)\end{array}$ & $\begin{array}{l}{ }^{235} \mathrm{U} \\
(n, \gamma)\end{array}$ & $\begin{array}{l}103.38 \\
\pm 0.01\end{array}$ & $\begin{array}{l}103.38 \\
\pm 0.01\end{array}$ & $\begin{array}{l}103.41 \\
\pm 0.01\end{array}$ & $\begin{array}{l}103.39 \\
\pm 0.01\end{array}$ & $\begin{array}{l}103.38 \\
\pm 0.01\end{array}$ & $\begin{array}{l}103.38 \\
\pm 0.01\end{array}$ \\
\hline & $\begin{array}{l}{ }^{235} \mathrm{U} \\
(n, f)\end{array}$ & $\begin{array}{l}{ }^{235} \mathrm{U} \\
(n, f)\end{array}$ & $\begin{array}{l}69.71 \\
\pm 0.01\end{array}$ & $\begin{array}{l}69.77 \\
\pm 0.01\end{array}$ & $\begin{array}{l}69.80 \\
\pm 0.01\end{array}$ & $\begin{array}{l}69.95 \\
\pm 0.01\end{array}$ & $\begin{array}{l}69.80 \\
\pm 0.01\end{array}$ & $\begin{array}{l}69.88 \\
\pm 0.01\end{array}$ \\
\hline & $\begin{array}{l}{ }^{27} \mathrm{Al} \\
(n, n)\end{array}$ & $\begin{array}{l}{ }^{27} \mathrm{Al} \\
(n, n)\end{array}$ & $\begin{array}{l}147.30 \\
\pm 0.07\end{array}$ & $\begin{array}{l}144.61 \\
\pm 0.07\end{array}$ & $\begin{array}{l}146.57 \\
\pm 0.07\end{array}$ & $\begin{array}{l}154.01 \\
\pm 0.08\end{array}$ & $\begin{array}{l}143.87 \\
\pm 0.07\end{array}$ & $\begin{array}{l}149.45 \\
\pm 0.08\end{array}$ \\
\hline & $\begin{array}{l}{ }^{27} \mathrm{Al} \\
\left(n, n^{\prime}\right)\end{array}$ & $\begin{array}{l}27 \mathrm{Al} \\
\left(n, n^{\prime}\right)\end{array}$ & $\begin{array}{l}142.17 \\
\pm 0.03\end{array}$ & $\begin{array}{l}142.97 \\
\pm 0.03\end{array}$ & $\begin{array}{l}143.74 \\
\pm 0.03\end{array}$ & $\begin{array}{l}146.16 \\
\pm 0.03\end{array}$ & $\begin{array}{l}144.26 \\
\pm 0.03\end{array}$ & $\begin{array}{l}144.64 \\
\pm 0.03\end{array}$ \\
\hline & $\begin{array}{l}{ }^{27} \mathrm{Al} \\
(n, \gamma)\end{array}$ & $\begin{array}{l}{ }^{27} \mathrm{Al} \\
(n, \gamma)\end{array}$ & $\begin{array}{l}43.41 \\
\pm 0.01\end{array}$ & $\begin{array}{l}43.45 \\
\pm 0.01\end{array}$ & $\begin{array}{l}43.48 \\
\pm 0.01\end{array}$ & $\begin{array}{l}43.63 \\
\pm 0.01\end{array}$ & $\begin{array}{l}43.50 \\
\pm 0.01\end{array}$ & $\begin{array}{l}43.56 \\
\pm 0.01\end{array}$ \\
\hline \multirow[t]{5}{*}{ Polyethylene } & $\begin{array}{l}{ }^{* 1} \mathrm{H} \\
(n, n)\end{array}$ & $\begin{array}{l}{ }^{* 1} \mathrm{H} \\
(n, n)\end{array}$ & $\begin{array}{l}192.70 \\
\pm 0.02\end{array}$ & $\begin{array}{l}191.94 \\
\pm 0.02\end{array}$ & $\begin{array}{l}192.73 \\
\pm 0.02\end{array}$ & $\begin{array}{l}196.16 \\
\pm 0.02\end{array}$ & $\begin{array}{l}192.90 \\
\pm 0.02\end{array}$ & $\begin{array}{l}193.34 \\
\pm 0.02\end{array}$ \\
\hline & $\begin{array}{l}{ }^{* 1} \mathrm{H} \\
(n, \gamma)\end{array}$ & $\begin{array}{l}{ }^{* 1} \mathrm{H} \\
(n, \gamma)\end{array}$ & $\begin{array}{l}120.60 \\
\pm 0.01\end{array}$ & $\begin{array}{l}119.22 \\
\pm 0.01\end{array}$ & $\begin{array}{l}118.78 \\
\pm 0.01\end{array}$ & $\begin{array}{l}113.26 \\
\pm 0.01\end{array}$ & $\begin{array}{l}117.20 \\
\pm 0.01\end{array}$ & $\begin{array}{l}115.26 \\
\pm 0.01\end{array}$ \\
\hline & $\begin{array}{l}\mathrm{C}(n, \\
n)\end{array}$ & $\begin{array}{l}\mathrm{C}(n, \\
n)\end{array}$ & $\begin{array}{l}61.06 \\
\pm 0.01\end{array}$ & $\begin{array}{l}60.62 \\
\pm 0.01 \\
\end{array}$ & $\begin{array}{l}60.81 \\
\pm 0.01 \\
\end{array}$ & $\begin{array}{l}61.24 \\
\pm 0.01 \\
\end{array}$ & $\begin{array}{l}60.90 \\
\pm 0.01\end{array}$ & $\begin{array}{l}60.97 \\
\pm 0.01 \\
\end{array}$ \\
\hline & $\begin{array}{l}\mathrm{C}(n, \\
\left.n^{\prime}\right)\end{array}$ & $\begin{array}{l}\mathrm{C}(n, \\
\left.n^{\prime}\right)\end{array}$ & $\begin{array}{l}24.88 \\
\pm 0.01\end{array}$ & $\begin{array}{l}25.41 \\
\pm 0.01\end{array}$ & $\begin{array}{l}24.66 \\
\pm 0.01 \\
\end{array}$ & $\begin{array}{l}24.53 \\
\pm 0.01\end{array}$ & $\begin{array}{l}24.94 \\
\pm 0.01\end{array}$ & $\begin{array}{l}24.66 \\
\pm 0.01\end{array}$ \\
\hline & $\begin{array}{l}\mathrm{C}(n, \\
n)\end{array}$ & $\begin{array}{l}\mathrm{C}(n, \\
n)\end{array}$ & $\begin{array}{l}-24.07 \\
\pm 0.01\end{array}$ & $\begin{array}{l}-24.37 \\
\pm 0.01\end{array}$ & $\begin{array}{l}-23.94 \\
\pm 0.01\end{array}$ & $\begin{array}{l}-23.88 \\
\pm 0.01\end{array}$ & $\begin{array}{l}-24.10 \\
\pm 0.01\end{array}$ & $\begin{array}{l}-23.95 \\
\pm 0.01\end{array}$ \\
\hline \multirow[t]{2}{*}{$\begin{array}{l}\text { Aluminum } \\
\text { sheath }\end{array}$} & $\begin{array}{l}{ }^{* 27} \mathrm{~A} 1 \\
(n, n)\end{array}$ & $\begin{array}{l}\mathrm{Al}(n, \\
n)\end{array}$ & $\begin{array}{l}93.22 \\
\pm 0.03\end{array}$ & $\begin{array}{l}92.56 \\
\pm 0.03\end{array}$ & $\begin{array}{l}95.85 \\
\pm 0.03\end{array}$ & $\begin{array}{l}96.56 \\
\pm 0.03\end{array}$ & $\begin{array}{l}95.91 \\
\pm 0.03\end{array}$ & $\begin{array}{l}96.67 \\
\pm 0.03\end{array}$ \\
\hline & $\begin{array}{l}{ }^{* 27} \mathrm{Al} \\
\left(n, n^{\prime}\right)\end{array}$ & $\begin{array}{l}\mathrm{Al}(n, \\
\left.n^{\prime}\right)\end{array}$ & $\begin{array}{l}49.57 \\
\pm 0.01\end{array}$ & $\begin{array}{l}49.80 \\
\pm 0.01\end{array}$ & $\begin{array}{l}49.80 \\
\pm 0.01\end{array}$ & $\begin{array}{l}50.28 \\
\pm 0.01\end{array}$ & $\begin{array}{l}50.28 \\
\pm 0.01\end{array}$ & $\begin{array}{l}49.92 \\
\pm 0.01\end{array}$ \\
\hline Control rod & $\begin{array}{l}{ }^{10} \mathrm{~B} \\
(n, \gamma)\end{array}$ & $\begin{array}{l}{ }^{10} \mathrm{~B} \\
(n, \gamma)\end{array}$ & $9.5 \mathrm{E}-08$ & $1.0 \mathrm{E}-03$ & $9.5 \mathrm{E}-04$ & $5.42 \mathrm{E}-03$ & $1.59 \mathrm{E}-03$ & $3.52 \mathrm{E}-03$ \\
\hline
\end{tabular}

*With consideration of thermal scattering law $S(\alpha, \beta)$ 
Table 8.13 Breakdown of the uncertainty [pcm] of $k_{\text {eff }}$ in nuclides and nuclear reactions in E3 core (Ref. [2])

\begin{tabular}{|c|c|c|c|c|c|c|c|c|}
\hline \multirow[t]{2}{*}{ Component } & \multirow{2}{*}{\multicolumn{2}{|c|}{$\begin{array}{l}\text { Nuclides reaction } \\
\text { versus reaction }\end{array}$}} & \multicolumn{6}{|l|}{ Case } \\
\hline & & & \multirow{2}{*}{$\begin{array}{l}\text { II-1 } \\
726.35 \\
\pm 0.25\end{array}$} & \multirow{2}{*}{$\begin{array}{l}\text { II-2 } \\
729.64 \\
\pm 0.25\end{array}$} & \multirow{2}{*}{$\begin{array}{l}\text { II-3 } \\
731.48 \\
\pm 0.25\end{array}$} & \multirow{2}{*}{$\begin{array}{l}\text { II-4 } \\
735.58 \\
\pm 0.25\end{array}$} & \multirow{2}{*}{$\begin{array}{l}\text { II-5 } \\
735.63 \\
\pm 0.25\end{array}$} & \multirow{2}{*}{\begin{tabular}{|l|} 
II-6 \\
735.89 \\
\pm 0.25 \\
\end{tabular}} \\
\hline $\mathrm{HEU}$ & ${ }^{235} \mathrm{U} \chi$ & ${ }^{235} \mathrm{U} \chi$ & & & & & & \\
\hline & ${ }^{235} \mathrm{U} \bar{v}$ & ${ }^{235} \mathrm{U} \bar{v}$ & $\begin{array}{l}379.52 \\
\pm 0.01\end{array}$ & $\begin{array}{l}379.50 \\
\pm 0.01\end{array}$ & $\begin{array}{l}379.49 \\
\pm 0.01\end{array}$ & $\begin{array}{l}379.46 \\
\pm 0.01\end{array}$ & $\begin{array}{l}379.47 \\
\pm 0.01\end{array}$ & $\begin{array}{l}379.47 \\
\pm 0.01\end{array}$ \\
\hline & $\begin{array}{l}{ }^{235} \mathrm{U}(n, \\
\gamma)\end{array}$ & $\begin{array}{l}{ }^{235} \mathrm{U}(n, \\
\gamma)\end{array}$ & $\begin{array}{l}182.95 \\
\pm 0.01\end{array}$ & $\begin{array}{l}182.85 \\
\pm 0.01\end{array}$ & $\begin{array}{l}182.86 \\
\pm 0.01\end{array}$ & $\begin{array}{l}182.70 \\
\pm 0.01\end{array}$ & $\begin{array}{l}182.77 \\
\pm 0.01\end{array}$ & $\begin{array}{l}182.75 \\
\pm 0.01\end{array}$ \\
\hline & $\begin{array}{l}{ }_{f}^{235} \mathrm{U}(n, \\
\end{array}$ & $\begin{array}{l}{ }_{f}^{235} \mathrm{U}(n, \\
\end{array}$ & $\begin{array}{l}126.42 \\
\pm 0.01\end{array}$ & $\begin{array}{l}126.44 \\
\pm 0.01\end{array}$ & $\begin{array}{l}126.44 \\
\pm 0.01\end{array}$ & $\begin{array}{l}126.46 \\
\pm 0.01\end{array}$ & $\begin{array}{l}126.45 \\
\pm 0.01\end{array}$ & $\begin{array}{l}126.46 \\
\pm 0.01\end{array}$ \\
\hline & $\begin{array}{l}{ }^{235} \mathrm{U}(n, \\
f)\end{array}$ & $\begin{array}{l}{ }^{235} \mathrm{U}(n, \\
\gamma)\end{array}$ & $\begin{array}{l}109.66 \\
\pm 0.01\end{array}$ & $\begin{array}{l}109.76 \\
\pm 0.01\end{array}$ & $\begin{array}{l}109.74 \\
\pm 0.01\end{array}$ & $\begin{array}{l}109.87 \\
\pm 0.01\end{array}$ & $\begin{array}{l}109.82 \\
\pm 0.01\end{array}$ & $\begin{array}{l}109.84 \\
\pm 0.01\end{array}$ \\
\hline & $\begin{array}{l}{ }^{27} \mathrm{Al}(n, \\
n)\end{array}$ & $\begin{array}{l}{ }^{27} \mathrm{Al}(n, \\
n)\end{array}$ & $\begin{array}{l}40.01 \\
\pm 0.01\end{array}$ & $\begin{array}{l}39.38 \\
\pm 0.01\end{array}$ & $\begin{array}{l}40.38 \\
\pm 0.01\end{array}$ & $\begin{array}{l}40.25 \\
\pm 0.01\end{array}$ & $\begin{array}{l}41.52 \\
\pm 0.01\end{array}$ & $\begin{array}{l}41.07 \\
\pm 0.01\end{array}$ \\
\hline & $\begin{array}{l}{ }^{27} \mathrm{Al}(n, \\
\left.n^{\prime}\right)\end{array}$ & $\begin{array}{l}{ }^{27} \mathrm{Al}(n, \\
\left.n^{\prime}\right)\end{array}$ & $\begin{array}{l}37.25 \\
\pm 0.01\end{array}$ & $\begin{array}{l}37.68 \\
\pm 0.01\end{array}$ & $\begin{array}{l}38.11 \\
\pm 0.01\end{array}$ & $\begin{array}{l}37.84 \\
\pm 0.01\end{array}$ & $\begin{array}{l}37.66 \\
\pm 0.01\end{array}$ & $\begin{array}{l}37.64 \\
\pm 0.01\end{array}$ \\
\hline \multirow[t]{5}{*}{ Polyethylene } & $\begin{array}{l}{ }^{* 1} \mathrm{H}(n, \\
\gamma)\end{array}$ & $\begin{array}{l}{ }^{* 1} \mathrm{H}(n, \\
\gamma)\end{array}$ & $\begin{array}{l}217.00 \\
\pm 0.01\end{array}$ & $\begin{array}{l}215.12 \\
\pm 0.01\end{array}$ & $\begin{array}{l}214.89 \\
\pm 0.01\end{array}$ & $\begin{array}{l}211.03 \\
\pm 0.01\end{array}$ & $\begin{array}{l}211.60 \\
\pm 0.01\end{array}$ & $\begin{array}{l}212.23 \\
\pm 0.01\end{array}$ \\
\hline & $\begin{array}{l}{ }^{* 1} \mathrm{H}(n, \\
n)\end{array}$ & $\begin{array}{l}{ }^{* 1} \mathrm{H}(n, \\
n)\end{array}$ & $\begin{array}{l}188.58 \\
\pm 0.03\end{array}$ & $\begin{array}{l}188.17 \\
\pm 0.03\end{array}$ & $\begin{array}{l}187.72 \\
\pm 0.03\end{array}$ & $\begin{array}{l}191.17 \\
\pm 0.03\end{array}$ & $\begin{array}{l}190.96 \\
\pm 0.03\end{array}$ & $\begin{array}{l}190.40 \\
\pm 0.03\end{array}$ \\
\hline & $\mathrm{C}(n, n)$ & $C(n, n)$ & $\begin{array}{l}57.98 \\
\pm 0.01\end{array}$ & $\begin{array}{l}57.70 \\
\pm 0.01\end{array}$ & $\begin{array}{l}57.90 \\
\pm 0.01\end{array}$ & $\begin{array}{l}58.40 \\
\pm 0.01\end{array}$ & $\begin{array}{l}58.44 \\
\pm 0.01\end{array}$ & $\begin{array}{l}58.42 \\
\pm 0.01\end{array}$ \\
\hline & $C\left(n, n^{\prime}\right)$ & $C\left(n, n^{\prime}\right)$ & $\begin{array}{l}31.96 \\
\pm 0.01 \\
\end{array}$ & $\begin{array}{l}32.25 \\
\pm 0.01 \\
\end{array}$ & $\begin{array}{l}32.29 \\
\pm 0.01\end{array}$ & $\begin{array}{l}31.79 \\
\pm 0.01\end{array}$ & $\begin{array}{l}32.25 \\
\pm 0.01\end{array}$ & $\begin{array}{l}32.37 \\
\pm 0.01\end{array}$ \\
\hline & $C(n, n)$ & $C\left(n, n^{\prime}\right)$ & $\begin{array}{l}-28.83 \\
\pm 0.01 \\
\end{array}$ & $\begin{array}{l}-28.94 \\
\pm 0.01\end{array}$ & $\begin{array}{l}-29.01 \\
\pm 0.01\end{array}$ & $\begin{array}{l}-28.70 \\
\pm 0.01 \\
\end{array}$ & $\begin{array}{l}-28.98 \\
\pm 0.01\end{array}$ & $\begin{array}{l}-28.94 \\
\pm 0.01\end{array}$ \\
\hline \multirow[t]{3}{*}{$\begin{array}{l}\text { Aluminum } \\
\text { sheath }\end{array}$} & $\begin{array}{l}{ }_{n}^{* 27} \mathrm{Al}(n, \\
n)\end{array}$ & $\begin{array}{l}{ }_{n}^{* 27} \mathrm{Al}(n, \\
\end{array}$ & $\begin{array}{l}68.36 \\
\pm 0.02\end{array}$ & $\begin{array}{l}69.46 \\
\pm 0.02\end{array}$ & $\begin{array}{l}68.11 \\
\pm 0.02\end{array}$ & $\begin{array}{l}68.72 \\
\pm 0.02\end{array}$ & $\begin{array}{l}70.06 \\
\pm 0.02\end{array}$ & $\begin{array}{l}69.49 \\
\pm 0.02\end{array}$ \\
\hline & $\begin{array}{l}{ }^{* 27} \mathrm{Al}(n \\
\left.n^{\prime}\right)\end{array}$ & $\begin{array}{l}{ }^{* 27} \mathrm{Al}(n, \\
\left.n^{\prime}\right)\end{array}$ & $\begin{array}{l}37.69 \\
\pm 0.01\end{array}$ & $\begin{array}{l}37.50 \\
\pm 0.01\end{array}$ & $\begin{array}{l}37.67 \\
\pm 0.01\end{array}$ & $\begin{array}{l}37.61 \\
\pm 0.01\end{array}$ & $\begin{array}{l}37.42 \\
\pm 0.01\end{array}$ & $\begin{array}{l}37.60 \\
\pm 0.01\end{array}$ \\
\hline & $\begin{array}{l}{ }^{* 27} \mathrm{Al}(n \\
\gamma)\end{array}$ & $\begin{array}{l}*^{* 27} \mathrm{Al}(n, \\
\gamma)\end{array}$ & $\begin{array}{l}30.81 \\
\pm 0.01\end{array}$ & $\begin{array}{l}30.43 \\
\pm 0.01\end{array}$ & $\begin{array}{l}30.39 \\
\pm 0.01\end{array}$ & $\begin{array}{l}29.52 \\
\pm 0.01\end{array}$ & $\begin{array}{l}29.66 \\
\pm 0.01\end{array}$ & $\begin{array}{l}29.82 \\
\pm 0.01\end{array}$ \\
\hline Control rod & $\begin{array}{l}{ }^{10} \mathrm{~B}(n, \\
\gamma)\end{array}$ & $\begin{array}{l}{ }^{10} \mathrm{~B}(n, \\
\gamma)\end{array}$ & $1.1 \mathrm{E}-07$ & $1.1 \mathrm{E}-03$ & $1.0 \mathrm{E}-03$ & $3.5 \mathrm{E}-03$ & $2.9 \mathrm{E}-03$ & $2.5 \mathrm{E}-03$ \\
\hline
\end{tabular}

*With consideration of thermal scattering law $S(\alpha, \beta)$

\subsubsection{Tolerance of HEU Plate}

For the variation in manufacturing tolerance of HEU plates shown in Table 8.1, uncertainty was evaluated with MCNP6.1 together with ENDF/B-VII.1 with the same number of histories as was reactivity evaluation, as shown in Tables 8.14 and 8.15. Based on the evaluation of the uncertainty for HEU plates, the uncertainty of the 


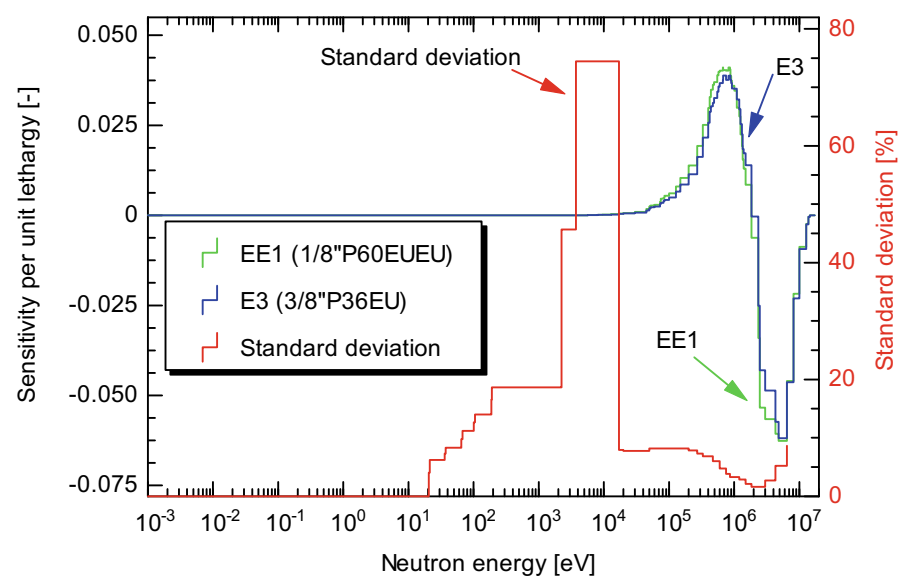

Fig. 8.8 Sensitivity profile and standard deviation covariance data for $\chi$ value of ${ }^{235} U$ (Ref. [2])

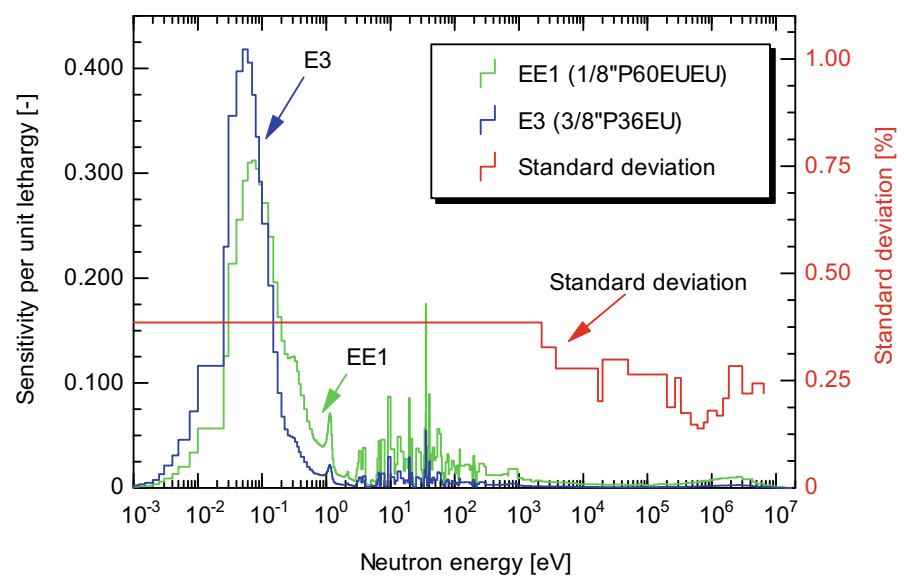

Fig. 8.9 Sensitivity profile and standard deviation covariance data for $\bar{v}$ value of ${ }^{235} \mathrm{U}$ (Ref. [2])

enrichment (4-14 pcm), length of sides (5 pcm), and thickness (10 pcm) was small regardless of the position of the control rods. Nonetheless, the difference of neutron spectra demonstrated its dependence on the uncertainty between EE1 and E3 cores, emphasizing especially the variation of total number of fuel plates: 3000 and 756 plates in EE1 and E3 cores, respectively. Additionally, the uncertainty attributed to variation in manufacturing tolerance was smaller than that induced by nuclear data, indicating that uncertainty induced by nuclear data is reasonable for the accuracy of criticality at KUCA. 


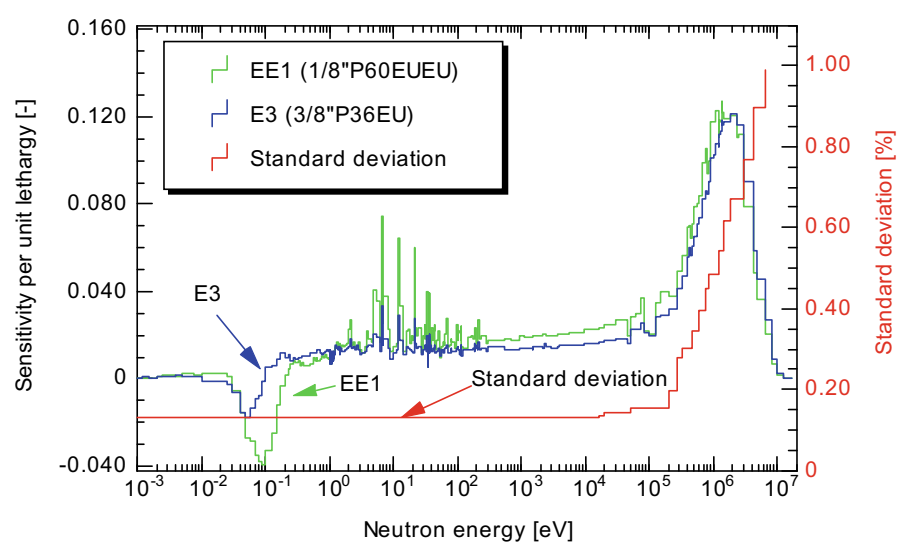

Fig. 8.10 Sensitivity profile and standard deviation covariance data for $\mathrm{H}(n, n)$ reactions (polyethylene) (Ref. [2])

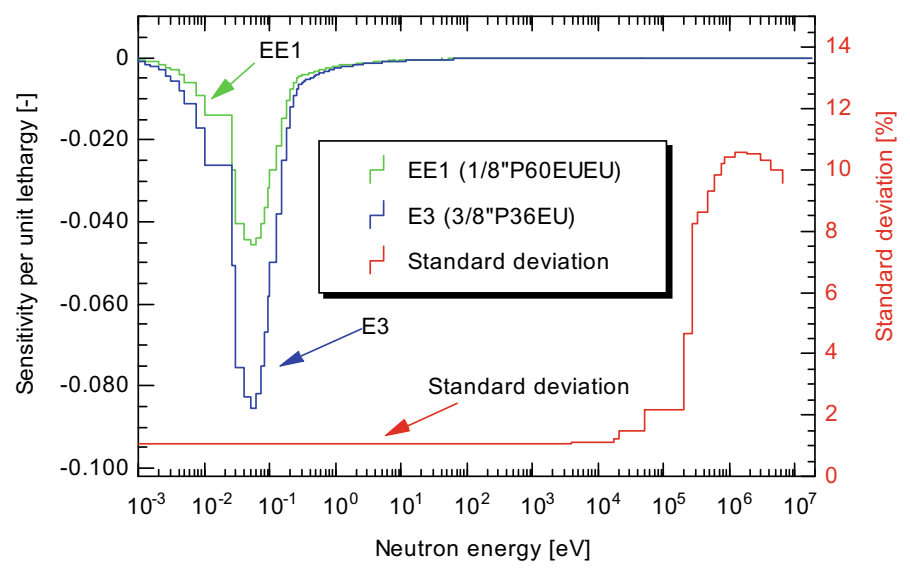

Fig. 8.11 Sensitivity profile and standard deviation in covariance data for $\mathrm{H}(n, \gamma)$ reactions (polyethylene) (Ref. [2])

\subsubsection{Reproducibility of Control Rod Position}

The uncertainty induced by the reproducibility of control rod positions, as shown in Tables 8.14 and 8.15 , indicated about $3 \mathrm{pcm}$ even at the withdrawal (no insertion) of control rods in Cases I-1 and II-1, showing an index of accuracy induced by the approximation in Eq. (8.20). By considering the index from the control rod insertion pattern, the uncertainty attributed to varying control rod position was evaluated about $8 \mathrm{pcm}$ depending slightly on the insertion pattern. Here, the evaluated uncertainty was nearly the same as the experimental uncertainty in the reactivity shown in Tables 8.10 


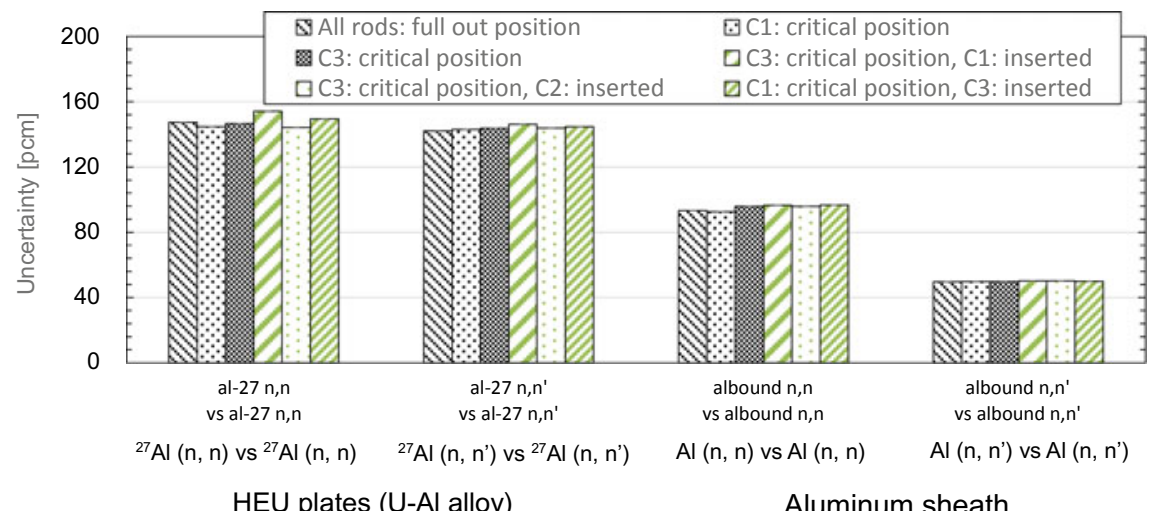

Fig. 8.12 Uncertainty of aluminum in HEU (U-Al alloy) plates, aluminum sheath, and control rod guide tube induced by nuclear data in EE1 core (Ref. [2])

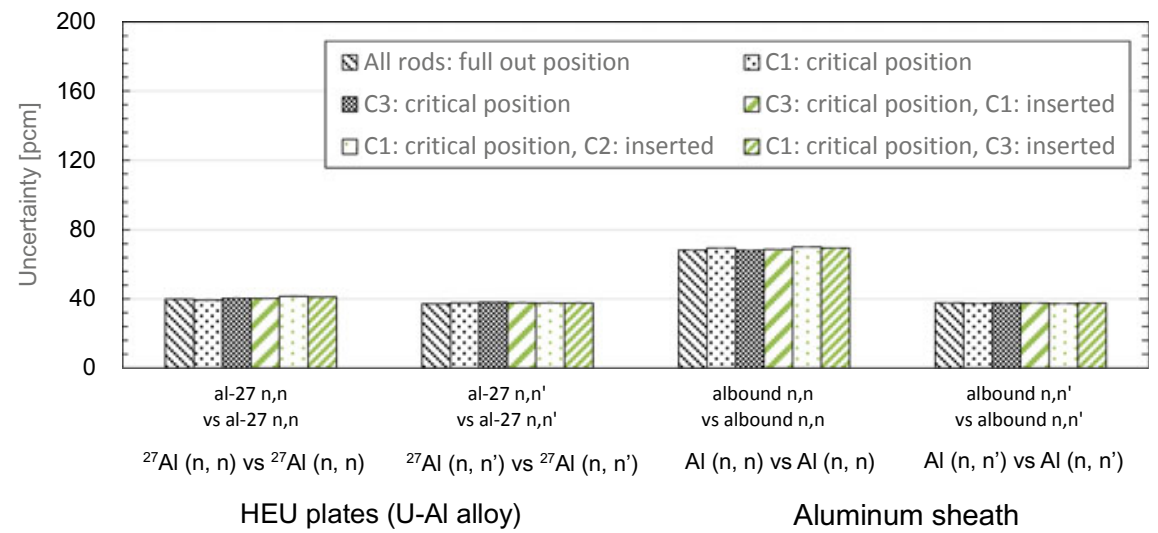

Fig. 8.13 Uncertainty of aluminum in HEU (U-Al alloy) plates, aluminum sheath, and control rod guide tube induced by nuclear data in E3 core (Ref. [2])

and 8.11 (2 pcm through $11 \mathrm{pcm})$, demonstrating that the measured reactivity was slightly varied by the position of control rods.

\subsection{Conclusion}

Sensitivity and uncertainty analyses were conducted with the combined use of experimental results (excess reactivity and control rod worth) carried out at KUCA and numerical simulations by the MCNP6.1 calculations, the SRAC2006 and MARBLE code systems. The experimental value was compared with the calculated one by 


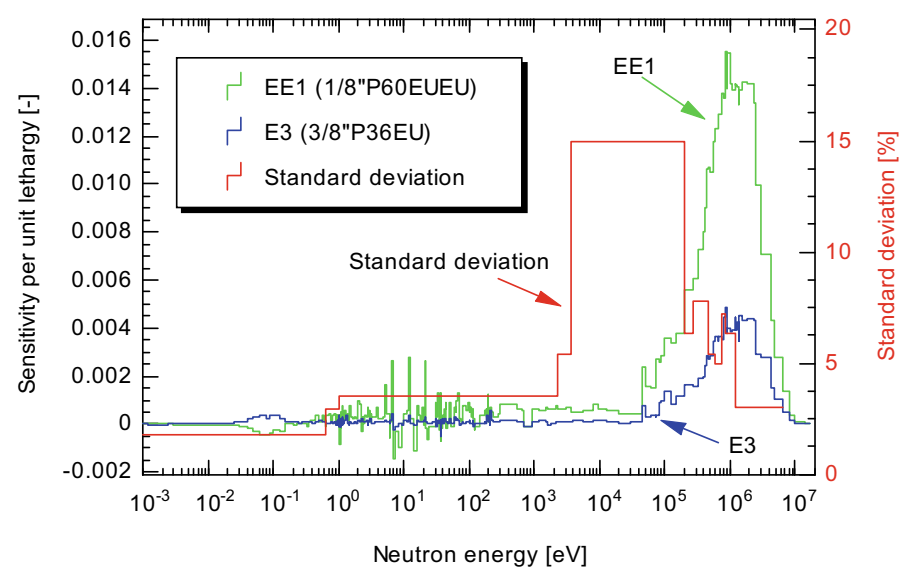

Fig. 8.14 Sensitivity profile and standard deviation in covariance data for ${ }^{27} \mathrm{Al}(n, \gamma)$ reactions (HEU plate) (Ref. [2])

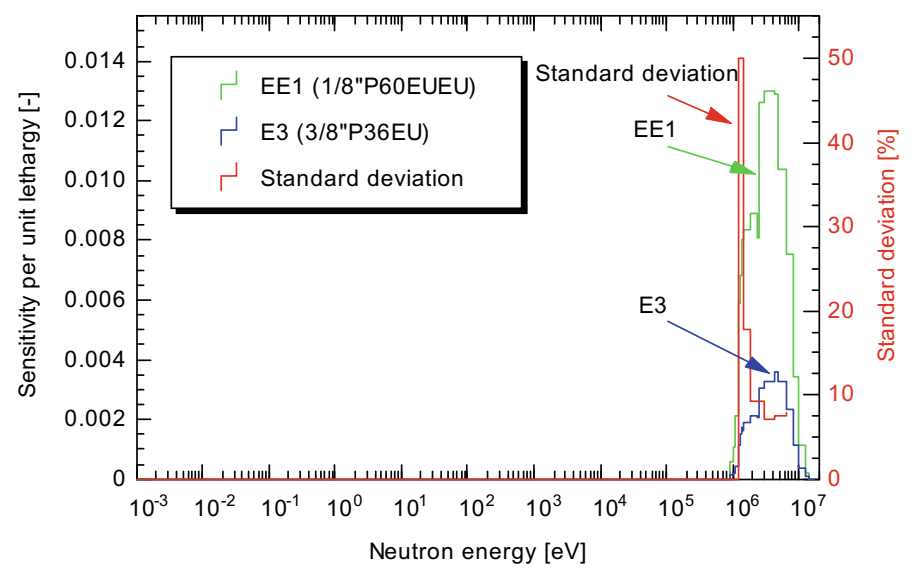

Fig. 8.15 Sensitivity profile and standard deviation in covariance data for ${ }^{27} \mathrm{Al}\left(n, n^{\prime}\right)$ reactions (HEU plate) (Ref. [2])

Table 8.14 Uncertainty [pcm] of $k_{\text {eff }}$ attributed to manufacturing variation in HEU plates in Table 8.1 and reproducibility of control rods for EE1 core (Ref. [2])

\begin{tabular}{l|l|l|l|l|l}
\hline Case & $\begin{array}{l}\text { Enrichment of } \\
{ }^{235} \mathrm{U}\end{array}$ & Vertical length & $\begin{array}{l}\text { Horizontal } \\
\text { length }\end{array}$ & Thickness & $\begin{array}{l}\text { Reproducibility } \\
\text { of control rod }\end{array}$ \\
\hline $\mathrm{I}-1$ & $4.25 \pm 0.09$ & $4.19 \pm 0.38$ & $3.68 \pm 0.43$ & $9.44 \pm 0.23$ & $3.23 \pm 3.55$ \\
\hline $\mathrm{I}-2$ & $4.21 \pm 0.09$ & $3.80 \pm 0.40$ & $4.10 \pm 0.41$ & $9.60 \pm 0.23$ & $2.22 \pm 3.77$ \\
\hline $\mathrm{I}-3$ & $4.08 \pm 0.09$ & $4.51 \pm 0.34$ & $3.59 \pm 0.40$ & $9.68 \pm 0.23$ & $7.22 \pm 3.57$ \\
\hline $\mathrm{I}-4$ & $4.21 \pm 0.09$ & $4.59 \pm 0.39$ & $4.40 \pm 0.38$ & $9.68 \pm 0.23$ & $5.54 \pm 3.56$ \\
\hline $\mathrm{I}-5$ & $4.14 \pm 0.09$ & $3.69 \pm 0.37$ & $4.22 \pm 0.41$ & $10.08 \pm 0.23$ & $4.65 \pm 3.56$ \\
\hline $\mathrm{I}-6$ & $4.13 \pm 0.09$ & $4.15 \pm 0.38$ & $4.23 \pm 0.41$ & $9.80 \pm 0.23$ & $4.28 \pm 3.56$ \\
\hline
\end{tabular}


Table 8.15 Uncertainty [pcm] of $k_{\text {eff }}$ attributed to manufacturing variation in HEU plates in Table 8.1 and reproducibility of control rods for E3 core (Ref. [2])

\begin{tabular}{l|l|l|l|l|l}
\hline Case & $\begin{array}{l}\text { Enrichment of } \\
235 \mathrm{U}\end{array}$ & Vertical length & Horizontal length & Thickness & $\begin{array}{l}\text { Reproducibility of } \\
\text { control rod }\end{array}$ \\
\hline II-1 & $13.20 \pm 0.11$ & $3.00 \pm 0.25$ & $3.09 \pm 0.28$ & $8.40 \pm 0.41$ & $2.47 \pm 3.16$ \\
\hline II-2 & $13.22 \pm 0.11$ & $3.15 \pm 0.31$ & $3.41 \pm 0.35$ & $7.71 \pm 0.41$ & $2.90 \pm 3.17$ \\
\hline II-3 & $13.27 \pm 0.11$ & $3.00 \pm 0.29$ & $3.19 \pm 0.30$ & $8.11 \pm 0.41$ & $3.56 \pm 317$ \\
\hline II-4 & $13.36 \pm 0.11$ & $3.10 \pm 0.29$. & $2.60 \pm 0.31$ & $8.04 \pm 0.41$ & $6.78 \pm 3.14$ \\
\hline II-5 & $13.50 \pm 0.11$ & $2.90 \pm 0.32$ & $3.03 \pm 0.31$ & $7.42 \pm 0.41$ & $3.99 \pm 3.16$ \\
\hline II-6 & $13.30 \pm 0.11$ & $3.08 \pm 0.28$ & $2.89 \pm 0.32$ & $7.93 \pm 0.41$ & $4.10 \pm 3.15$ \\
\hline
\end{tabular}

the deterministic approach with the covariance data of JENDL-4.0. Sensitivity and uncertainty analyses demonstrated that the impact of ${ }^{27} \mathrm{Al}$ and ${ }^{235} \mathrm{U}$ was remarkably large in the KUCA A cores, respectively. Moreover, the numerical results revealed the quantitative evaluation (about $150 \mathrm{pcm}$ ) of uncertainty induced by the JENDL4.0 data library in the A cores. Also, these results indicated that further investigation is needed of the numerical analyses of uncertainty of ${ }^{27} \mathrm{Al}$ composed mainly of core components in the $\mathrm{A}$ cores, with the use of ${ }^{27} \mathrm{Al}$ covariance data, in order to assess the effect of the uncertainty of ${ }^{27} \mathrm{Al}$ cross sections on reactivity.

To ensure the accuracy of criticality by experimental analyses at KUCA, the modeling of core configuration was examined through the comparison of excess reactivity and control rod worth between the calculation and the experiment in hard and soft spectrum cores. Furthermore, uncertainty was evaluated for manufacturing tolerance in HEU plates, for reproducibility of the control rod position, and for nuclear data. In the validation estimation of calculated $k_{\text {eff }}$ values in the modeling of reference core materials and core configurations with MCNP6.1 and SCALE6.2/KENO-VI, the bias in calculated $k_{\text {eff }}$ values showed that the difference in the spectrum was about 350 pcm in EE1 core and about $600 \mathrm{pcm}$ in E3 core. Moreover, uncertainty of $k_{\text {eff }}$ induced by nuclear data indicated about $950 \mathrm{pcm}$ for $k_{\text {eff }}$ evaluation with a slight variation in control rod position and core spectrum. In the breakdown of the uncertainty of $k_{\text {eff }}$ induced by nuclear data, the impact of ${ }^{235} \mathrm{U}$ was significantly dominant in over $90 \%$ for both cores. The sensitivities of $\mathrm{Al}$ in HEU plates and in $\mathrm{Al}$ sheaths were marked in fast neutron and resonance regions, leading to large uncertainty about $100 \mathrm{pcm}$ and $40 \mathrm{pcm}$ in EE1 and E3 cores, respectively. Also, uncertainty was evaluated about 10 and $8 \mathrm{pcm}$ in the tolerance of HEU plates and the reproducibility of control rod positions, respectively.

\section{References}

1. Pyeon CH, Yamanaka M, Ito M et al (2018) Uncertainty quantification of criticality in solidmoderated and -reflected cores at Kyoto University Critical Assembly. J Nucl Sci Technol 55:812 
2. Yamanaka M, Pyeon CH (2019) Benchmarks of criticality in solid-moderated and solidreflected core in at Kyoto University Critical Assembly. Nucl Sci Eng 193:404

3. Fukushima M, Kitamura Y, Kugo T et al (2016) Benchmark models for criticalities of FCA-IX assemblies with systematically changed neutron spectra. J Nucl Sci Technol 53:406

4. Goorley JT, James MR, Booth TE et al (2013) Initial MCNP6 release overview-MCNP6 version 1.0. LA-UR-13-22934

5. Shibata K, Iwamoto O, Nakagawa $\mathrm{T}$ et al (2011) JENDL-4.0: a new library for nuclear science and technology. J Nucl Sci Technol 48:1

6. Chadwick MB, Oblozinsky P, Herman M et al (2006) ENDF/V-II.0: next generation evaluated nuclear data library for nuclear science and technology. Nucl Data Sheet 107:2931

7. Okumura K, Kugo T, Kaneko Ket al (2007) SRAC2006: a comprehensive neutronic calculation code system. JAERI-Data/Code 2007-004

8. Yokoyama K, Hazama T, Numata K et al (2014) Development of comprehensive and versatile framework for reactor analysis, MARBLE. Ann Nucl Energy 66:51

9. Fowler TB, Vondy DR (1969) Nuclear reactor core analysis code: Citation. ORNL-TM-2496, rev. 2

10. Hara A, Takeda T, Kikuchi Y (1984) SAGEP: two-dimensional sensitivity analysis code based on generalized perturbation theory. JAERI-M 84-027

11. Hazama T, Chiba G, Sugino K et al (2006) Development of fine and ultra-fine group cell calculation code SLAROM-UF for fast reactor analysis. J Nucl Sci Technol 43:908

12. Pyeon CH, Fujimoto A, Sugawara T et al (2016) Validation of $\mathrm{Pb}$ nuclear data by Monte Carlo analyses of sample reactivity experiments at Kyoto University Critical Assembly. J Nucl Sci Technol 53:602

13. Usachev LN (1964) Perturbation theory for the breeding ratio and for other number ratios pertaining to various reactor processes. J Nucl Energy 18:571

14. Gandini A (1967) A generalized perturbation method for bi-linear functionals of the real and adjoint neutron fluxes. J Nucl Energy 21:755

15. Cecchini GP, Salvatores M (1971) Advances in the generalized perturbation theory. Nucl Sci Eng 46:304

16. Kobayashi K (1996) Reactor Physics. Corona Publishing Co. Ltd. Tokyo, Japan. [in Japanese]

17. Cacuci DG (2004) On the neutron kinetics and control of accelerator-driven systems. Nucl Sci Eng 148:55

18. Broadhead BL, Rearden BT, Hopper CM et al (2004) Sensitivity- and uncertainty-based criticality safety validation techniques. Nucl Sci Eng 146:340

19. Pyeon CH, Fujimoto A, Sugawara $\mathrm{T}$ et al (2017) Sensitivity and uncertainty analyses of lead sample reactivity experiments at Kyoto University Critical Assembly. Nucl Sci Eng 185:460

20. Dragt JB, Dekker JM, Grupperlaar H et al (1977) Methods of adjustment and error evaluation of neutron capture cross sections; application to fission product nuclides. Nucl Sci Eng 62:117

21. Cacuci DG, Inoescu-bujor M (2010) Best-estimate model calibration and prediction through experimental data assimilation: I. mathematical framework Nucl Sci Eng 165:18

22. Rearden BT, Jessee MA (2016) SCALE code system. ORNL/TM-2005/39 version 6.2.1

23. Nauchi Y, Kameyama T (2005) Proposal of direct calculation of kinetic parameters $\beta_{\text {eff }}$ and $\Lambda$ based on continuous energy Monte Carlo method. J Nucl Sci Technol 42:503

24. Meulekamp RK, van der Marck SC (2006) Calculating the effective delayed neutron fraction with Monte Carlo. Nucl Sci Eng 152:142

25. Rearden BT, Williams ML, Jessee MA et al (2011) Sensitivity and uncertainty analysis capabilities and data in SCALE. Nucl Technol 174:236

26. Perfetti CM, Rearden BT (2016) Development of a generalized perturbation theory method for sensitivity analysis using continuous-energy Monte Carlo methods. Nucl Sci Eng 182:354

27. OECD/NEA (2008) ICSBEP guide to the expression of uncertainties. https://www.oecd-nea. org/science/wpncs/icsbep/documents/UncGuide.pdf, Accessed 30 June 2020 
Open Access This chapter is licensed under the terms of the Creative Commons Attribution 4.0 International License (http://creativecommons.org/licenses/by/4.0/), which permits use, sharing, adaptation, distribution and reproduction in any medium or format, as long as you give appropriate credit to the original author(s) and the source, provide a link to the Creative Commons license and indicate if changes were made.

The images or other third party material in this chapter are included in the chapter's Creative Commons license, unless indicated otherwise in a credit line to the material. If material is not included in the chapter's Creative Commons license and your intended use is not permitted by statutory regulation or exceeds the permitted use, you will need to obtain permission directly from the copyright holder.

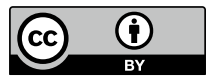

